\title{
Observed and projected Sea Surface Temperature seasonal changes in the Western English Channel from satellite data and CMIP5 multi-model ensemble.
}

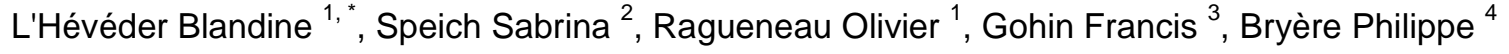 \\ ${ }^{1}$ LEMAR, IUEM Technopôle Brest-Iroise, rue Dumont d'Urville, 29280 Plouzané, FRANCE \\ ${ }^{2}$ LMD, ENS, 24 rue Lhomond, 75231 Paris cedex 05, FRANCE \\ ${ }^{3}$ IFREMER/DYNECO/PELAGOS, Centre Ifremer de Brest, 29280 Plouzané, FRANCE \\ ${ }^{4}$ ACRI-HE, 40 Quai de la douane, 29200 Brest, France \\ *Corresponding author : Blandine L'Hévéder, email address : blandine.Iheveder@Imd.jussieu.fr
}

\begin{abstract}
:
Seasonal Sea Surface Temperature (SST) changes in the Western English Channel have been estimated for the previous decades from high-resolution satellite data. Coastal seas, well separated from offshore waters by intense frontal structures, show colder SST by 1 to $2^{\circ} \mathrm{C}$ in summer. A significant warming trend is observed in the autumn season. This positive trend is stronger offshore, with an annual mean SST increase of $0.32^{\circ} \mathrm{C} /$ decade, but weaker in coastal waters $\left(0.23^{\circ} \mathrm{C} / \mathrm{decade}\right)$, where strong vertical mixing induced by tides and winds acts to reduce surface warming. The performance of an ensemble of CMIP5 climate model in simulating recent seasonal changes of SST in the region is estimated. The median of CMIP5 models reproduces very well the observed SST mean seasonal cycle in offshore waters but is less proficient in the coastal sector due to the coarse resolution of the models and the absence of tidal forcing and related processes. In the Iroise Sea, a region of intense biological activity located off the western tip of Brittany, the trend of the annual mean SST is relatively well simulated, albeit somewhat underestimated $(0.20 \%$ decade) and evenly distributed throughout the year. Here, the increase in annual mean SST in CMIP5 future scenarios simulations ranges from $0.5^{\circ} \mathrm{C}$ (RCP2.6) to $2.5^{\circ} \mathrm{C}$ (RCP8.5) by year 2100 , with a seasonal modulation leading to a more intense warming in summer than in winter. This increase in SST may strongly affect marine biology, particularly phytoplankton phenology, macro-algae biomass and benthic fauna, including exploited shellfish, in the Western English Channel.
\end{abstract}

Keywords : SST, Climate change, Western English Channel, CMIP5, regional study 


\section{Introduction}

Climate change will affect marine ecosystems in many different ways, through the alteration of the physical environment, biogeochemical cycles, biodiversity, and hence ecosystem structure and functioning (IPCC, 2014). The impact of climate change on biodiversity includes profound changes in species distribution and abundance, leading to global extinction and alteration of ecosystem services (Bellard et al., 2012). As a result of that, society, and in particular coastal communities, have to adapt to these changes (Millennium Ecosystem Assessment, 2005). In order to move towards adaptation and mitigation, there is a crucial need to improve the predictive capacity of models to depict future changes in the physical environment, especially at local or regional scale. Among the most crucial parameters to be studied, is sea surface temperature (SST). Temperature plays a fundamental role in ocean processes (circulation, stratification), in controlling the thermodynamic and kinetic characteristics of chemical and biogeochemical processes (degradation, dissolution, precipitation), in controlling the spatial distribution, the metabolic rates and the life cycle of marine flora (Bissinger et al., 2008; Chen, 2015) and fauna (Southward et al., 1995; Helmuth et al., 2006; Philippart et al, 2011; Thomas et al., 2016). The region of interest for this study is the Western English Channel, an oceanic region located off the western coasts of France, including the English Channel to the north, the Iroise Sea in the central-west portion and the Bay of Biscay at the southern end (Figure 1). Inside, two oceanic areas can be identified with different sea temperature sensitivities to global change. The first one, composed of the southern Brittany and the offshore waters of the Western English Channel, shows a seasonal stratification with frequent occurrences of a strong summer bloom of the harmful dinoflagellate Karenia mikimotoi on the warm side of the seasonal front of SST (Vanhoutte-Brunier et al., 2008, Hartmann et al., 2014). The second part of the region, essentially coastal but including also the central English Channel, is vertically well-mixed by tides (Gohin et al., 2015). In this area, a small increase in the water temperature could have a dramatic effect on the kelp Laminaria digitata, which is on the verge of local extinction due to the increase in sea temperature (Méléder et al., 2010, Raybaud et al., 2013). This is also a biogeographic boundary zone and, in recent years, warm water species 

Southward et al., 2005 ; Hawkins et al., 2008 ; Smale et al., 2013). Ecological problems related to SST change in the Western English Channel also include the alteration of nutrient delivery from land to sea, development of invasive species such as Crepidula fornicata, Spartina sp., Crassostrea giga, alteration of host-pathogen relationships and biological interactions (Poloczanska et al., 2008). Biologists try to better understand the response of these populations to increasing SST (Altizer et al., 2013).

There is a long history of research on the impacts of SST fluctuations on marine flora and fauna in the Western English Channel (Southward et al., 2005). The studies have shown both warm (18801890s, 1930-1950s) and cold periods (1960s to mid 1980s) before the recent period of rapid warming driven by anthropogenic climate change. The time window studied here is the one of recent warming. Over the last 30 years, the average surface temperature of the North Atlantic has risen (Rhein et al., 2013). This trend is not uniform because of regional variability, and not all areas of the Northeast Atlantic show the same long-term trends. However, the warming tendency of surface waters off the coasts of Brittany is similar to the North Atlantic average temperature trend (Dye et al., 2013). In the shallow seas of the Western English Channel, there is also substantial evidence of a warming over the past decades inferred from satellite observations (Cannaby and Hüsrevoglu, 2009, Saulquin and Gohin, 2010, Dye et al., 2013) and from regional modelling studies (Michel et al., 2009, Holt et al., 2012). On the wide northwest European continental shelf, global warming is modulated by mesoscale oceanic projections of future climate change have been made for several socio-economical scenarios with an 
92 processes or the long gravity waves associated with tides and wind-generated coastally trapped waves

93 (Holt et al., 2009). Besides, there are few published regional model simulations with sufficient

94 resolution to include shelf sea processes (e.g. tidal mixing fronts and coastal currents) and of sufficient

95 duration to investigate how atmospheric and/or oceanic fluxes drive the interannual to decadal

96 variability. Focusing on regional models including our study region --that is the French Atlantic

97 shoreline and the English Channel-- only two simulations cover the recent past. Holt et al. (2012)

98 have modelled the temperature over the European continental shelf with the Atlantic Margin

99 configuration of POLCOMS at $12 \mathrm{~km}$ resolution over the period 1960-2002. Michel et al. (2009) have

100 analyzed the temperature variability in the Bay of Biscay through a simulation performed with a global

101 configuration of NEMO (resolution of ${ }^{\sim} 20 \mathrm{~km}$, but tides not simulated) for the period 1958-2004.

102 Besides that, a higher number of modelling studies have been undertaken to model the changes in

103 ocean properties in the North Sea (Schrum, 2001, Meyer et al., 2011, Hjøllo et al., 2009 ) and in the

$104 \quad$ Irish Sea (Young and Holt, 2007) over the previous decades.

105 Downscaling of climate change scenarios have also been performed over the European continental shelf. Adlandsvik (2008) has compared a global climate simulation implemented with the BCM model under the SRES-A1B scenario (IPCC, 2007) with the associated downscaled simulation

108 with ROMS over the North Sea at $8 \mathrm{~km}$ resolution. Later on, Friocourt et al. (2012) have used two

109 hydrographic models for the downscaling of the same scenario over the North Sea, but only for a 20-

110 year period in the near future (2040s). Their study covers also the impacts on the phytoplankton

111 blooms using an ecological model. In the Irish Sea, Olbert et al. (2012) have downscaled the SRES-

112 A1B scenario using ECOMSED model at $2 \mathrm{~km}$ resolution. Finally, regarding our region of interest, an

113 ocean simulation of the European continental shelf has been performed with the regional ocean model

114 POLCOMS (at $12 \mathrm{~km}$ resolution) nested in the ESM HadCM3 under the SRES-A1B scenario (Holt et

115 al., 2010). Only the latter study covers the French Atlantic shoreline and the English Channel. It is

116 therefore necessary to go further and to investigate the variety of climate models responses to future

117 climate change in this region. Following Hawkins and Sutton (2009), the dominant sources of 
118 uncertainty for surface temperature prediction at regional scale are model and scenario uncertainties,

119 for time horizons of many decades or longer. To reduce model uncertainty, Foley (2010) has

120 demonstrated the efficiency of multi-model ensemble analysis.

The aim of this work is to evaluate the seasonal changes for SST in the Western English Channel in the previous decades (1980-now) and up to the end of the 21st century. To take into account the issues of uncertainty, we choose to analyze a multi-model ensemble of global climate models from the Coupled Model Intercomparison Project Phase 5 (CMIP5; Taylor et al., 2012), for

125 three Representative Concentration Pathway (RCP) scenarios (IPCC, 2014). For the previous decades, 126 the warming trend detected in CMIP5 models is validated by that estimated from satellite data, in the 127 three seas around Brittany at the grid scale of the models $(\sim 100 \mathrm{~km})$. Then, changes in the SST 128 seasonal cycle are assessed from the projections of CMIP5 models for future climate. The paper is 129 organized as follows. In Section 2, the data sets and methodology are described. In Section 3, an 130 overview of the changes in the SST seasonal cycle around Brittany over the last decades is presented.

131 Then, future changes are estimated for the Iroise Sea, region of special interest for its intense 132 biological activity. Section 4 addresses the expected impacts of the SST changes on the marine 133 ecosystems and concludes. (http://pcmdi9.1lnl.gov/esgf-web-fe/) for 13 CMIP5 models (cf. Table 1). Most of them are European models, in which the northern mid-latitude climate is likely to have been further validated. Only one (typically the first) ensemble member of each model is used. The past analysis is based on the historical simulation of the CMIP5 models for the period 1980-2005, and the future change on the projections for three RCP scenarios (RCP2.6, 4.5 and 8.5; Moss et al., 2010) over the period 2006-

142 2100. The historical simulations employ historical changes in the atmospheric composition reflecting 143 both anthropogenic and natural sources, and include time-evolving land cover information (Taylor et 6 
144 al., 2012). Then, the peak-and-decline RCP2.6 scenario is designed to meet the $2^{\circ} \mathrm{C}$ global average 145 warming target compared to pre-industrial conditions by 2100 (van Vuuren et al., 2011a). Radiative 146 forcing in RCP4.5 peaks at about $4.5 \mathrm{~W} / \mathrm{m} 2$ in year 2100 (Thomson et al., 2011). RCP8.5 assumes a 147 high rate of radiative forcing increase, peaking at $8.5 \mathrm{~W} / \mathrm{m} 2$ in year 2100 (Riahi et al., 2011).

Figure 1 pictures the regional seas located off the coasts of French Brittany : the English Channel, the Iroise Sea and the Bay of Biscay. Each of these seas has specific characteristics, linked to local topography, continental geometry, hydrology, and will be analyzed separately. Most of CMIP5 oceanic models have a typical low spatial resolution, of about $110 \mathrm{~km} \mathrm{x} 110 \mathrm{~km}$ at $48^{\circ} \mathrm{N}$ (see a typical CMIP5 grid cell on Figure 1), so that the regional seas are modelled by only some grid cells and shallow bathymetry is not well represented. The English Channel is not depicted in some models, nor is it connected to the North Sea in others (see detailed characteristics of the different grid topographies and geometries in Tab. 1). Tides and sub-mesoscale processes are not simulated but the complete ocean-atmosphere system is modelled, including heat and energy exchanges between ocean and atmosphere, essential to predict climate change.For each of the 13 CMIP5 ocean models, the grid points localized in each of these seas are selected, and daily SST data are spatially averaged to produce time series representative of the SST evolution in each sea. 2010); the OSTIA data provided by the Met Office using the Operational SST and Sea Ice Analysis (OSTIA) system described in Donlon et al. (2011); and the ODYSSEA data, also derived from multisensor data set incorporating microwave instruments, provided by MyOcean (Autret and Piollé, 2011). concatenating Ifremer AVHRR -derived SST data for 1986-2009, OSTIA data for 2010 and ODYSSEA data for 2011-2013. A comparison with an homogeneous time series covering the entire period, stemming from global low-resolution GHRSST, showed that the inhomogeneity of the high-resolution 
170 time series used here did not generate bias. The three sets of SST data were projected onto the same

171 regular grid $---0.075^{\circ}$ in longitude and $0.05^{\circ}$ in latitude --- allowing a high spatial resolution of

$172 \quad$ about $5 \mathrm{~km} \times 5 \mathrm{~km}$.

173 Analyzing the Ifremer AVHRR-SST satellite data over 1986-2006, Saulquin and Gohin (2010)

174 have shown that the mean annual warming of the SST was not spatially uniform in the English Channel,

175 due to local physical and hydrodynamic oceanic processes. Indeed, fronts develop in summer and

176 autumn, delimiting at the surface a warm area --at the north west of the Ushant front-- from a cold

177 one, both differing also in their vertical structure. The area with a warm surface layer lies in thermally

178 stratified open waters, while cold surface water lies in tidally mixed coastal waters. Figure 1 shows a

179 snapshot of the SST on 18th June 2003, where sharp discontinuities in SST can be observed in the

180 middle of the English Channel as well as in Iroise Sea (Iroise front) and off Ushant (Ushant front), with

181 SST differences across the fronts of about $2^{\circ} \mathrm{C}$. These fronts and their formation process have been

182 long and extensively studied (Pingree and Griffiths, 1978 ; Simpson et al., 1978; Mariette and Le

183 Cann, 1985 ; Le Boyer et al., 2009) and modelled (Muller et al., 2007 ; Cambon, 2008 ; Lazure et al.,

184 2009).

185 To take into account the spatial inhomogeneity of the SST in the seas surrounding Brittany, areas

186 with specific characteristics have been selected in each regional sea: «tidally mixed coastal waters 》,

187 hereafter denoted by TiMCW and 《 thermally stratified open waters 》, ThSOW. They are represented

188 in Figure 1. In the Bay of Biscay, tides are weaker and mainly ThSOW are observed.

Above all, a comparison of the satellite data spatially averaged to the same spatial scale as CMIP5

models is essential, in order to smooth the sub-mesoscale variability present in the satellite data but

192 not simulated in the models. For each of the three seas, a time series representing the large scale

193 behaviour of the satellite SST has been computed as its average over ThSOW and TiMCW boxes.

194

2.3 Methodology

8 

to characterize the SST seasonal cycle. They are computed from daily CMIP5 models data and highresolution satellite data, spatially averaged to typical model grid scale. A 《portrait diagram》of the different models performances to simulate the climatologic present-day observed SST seasonal cycle is shown, based on the indices. Over the last decades, trends in the indices are estimated in models and satellite data, to evaluate the past changes in the SST seasonal cycle and test their simulation in the models. Finally, future changes in the SST seasonal cycle are estimated from CMIP5 projections.

In order to quantify the warming trend and the SST seasonal cycle change, indices are necessary. For the atmosphere, the Expert Team on Climate Change Detection and Indices (ETCCDI) has defined a set of climate indices that provide a comprehensive overview of temperature and precipitation statistics focusing particularly on extreme aspects (Karl and Easterling, 1999, Klein Tank et al., 2009). and regional climate indices to evaluate the impact of oceano-climatic changes on marine ecosystems in the Bay of Biscay (Hemery et al., 2008). So far, no set of indices has been developed for oceaniconly climatic characteristics. compute these indices, daily data have been used to capture the most comprehensive signal. The 
To quantify the recent SST changes, linear trends in the SST monthly mean time series (Fig. 4) and in the indices time series (Figs. 5 to 7 ) were computed using a 《Kendall's tau based slope estimator 》developed by Wang and Swail (2001). This estimator is robust to the effect of outliers in the series and an iterative procedure prevents the Kendall test result from being affected by serial correlation of the series. This method has been widely used to compute trends in hydrometeorological series (e.g., Wang and Swail, 2001, Zhang et al., 2000) and taken up to estimate trends in climate extreme indices time series by Zhang et al. (2005). Throughout the paper, we only show trends considered as significant, taking a threshold level of $95 \%$.

\subsubsection{Model performance metrics} for various indices characterizing the mean SST seasonal cycle under present-day climate. respect to satellite observations over ThSOW and TiMCW (defined in Section 2.3.1). The indices are estimated at an annual frequency, as they characterize a feature of the annual cycle. For each index, we consider the climatology of its yearly time series over the common period between observations and models -- 1986-2004 --, at the model grid scale for models and averaged over ThSOW and TiMCW areas for satellite data. The climatologies are noted Ix for the model $\mathrm{X}$ and Iy for the satellite observations. The absolute value of the difference between models and observations climatologies is noted Exy=|Ix - Iy. 


$$
E^{\prime} x y=\frac{E_{X Y}-E_{m}}{E_{m}}
$$

with Em the median of the model-observation differences Exy for all models. ensemble, with respect to satellite observations over an area in the Iroise sea. The median Em represents typical model performance in the multi-model ensemble. E'xy values for all models and all indices obtained for both areas of the Iroise sea are summarized in a "portrait" diagram (Figure 3), discussed in Section 3.1.2.

\subsection{SST mean seasonal cycle in present-day climate}

The SST mean seasonal cycle in satellite data and in CMIP5 historical simulations has been evaluated for each of the three seas around Brittany (Figure 2). It is computed over the period 19802005 for CMIP5 models and 1986-2013 for satellite data.

In the observations, as expected, the SST mean seasonal cycles in TiMCW and ThSOW differ in summer and autumn. Due to the strong vertical mixing by tidal currents in coastal areas that prevents the seasonal thermocline from establishing in summer (Pingree and Griffiths, 1978, Mariette and Le Cann, 1985, Cambon, 2008), summer SSTs are colder in TiMCW than in ThSOW, with across front differences of about $1^{\circ} \mathrm{C}$ in the English Channel to $2^{\circ} \mathrm{C}$ in the Iroise Sea. Surface ThSOW cool earlier and faster in autumn, at the time when the seasonal thermocline disappears. In the TiMCW of Iroise Sea and English Channel, the mean SST seasonal cycles of satellite data are in good agreement with in situ-data from SOMLIT-Brest (at the outlet of the Bay of Brest) and SOMLIT-Astan (at the outlet of the Bay of Morlay) (Tréguer et al., 2014). 
to emphasize the absence of bias, distortion or shift in the median SST seasonal cycle of CMIP models,

270 especially in the Iroise Sea. In summer, we notice a higher dispersion between model estimates, with an

271 interquartile model spread ranging from $1.5^{\circ} \mathrm{C}$ in the Iroise Sea to $2^{\circ} \mathrm{C}$ in the English Channel. Each

272 model taken individually presents a bias, but if we consider CMIP5 models simulations as an ensemble

273 of climate simulations, the median of the ensemble represents well the observed SST mean seasonal

cycle. However, a few differences to the observations can be noted. In the Bay of Biscay, summer SST

are too warm by $1^{\circ} \mathrm{C}$. In the English Channel, winter SST are too cold by $1^{\circ} \mathrm{C}$. Finally, the characteristics of TiMCW ---colder summer SST-- are not simulated in CMIP5 models. This is due to the absence of simulation of sub-mesoscale processes and tides in global models, dominant factors for the SST in TiMCW. In ThSOW, processes of air-sea interactions predomines for the SST estimate (Esnaola et al., 2012). The latter are relatively well simulated in CMIP5 ocean-atmosphere coupled models, even if air-sea processes associated with sub-mesoscale oceanic structures have been demonstrated to increase the heat and energy budget of the ocean surface waters (Hogg et al., 2009, Chelton and Xie, 2010).

An inter-comparison of the different CMIP5 models performance in the Iroise Sea, using the metrics described in Section 2.3.3, is shown on the portrait diagram (Figure 3). It represents the relative magnitude of the 《model relative error $》$ for each index (columns) and for each model (rows). The magnitudes of the 《 model relative errors 》 are colour-coded, with colder (resp. warmer) colors corresponding to E’xy<0 (resp. E’xy $>0$ ) for models getting a better (resp. poorer) performance than others on average. In the first two rows, the performance of the 《mean 》and 《 median 》 of the multimodel ensemble is also displayed. performance in representing the observed SST. This result is consistent with the conclusions of Gleckler et al. (2008), Sillmann et al. (2013) and other multi-model studies. Indeed, some of the systematic bias in each of the individual models are canceled out in the multi-model mean or median. 
295 In ThSOW, the mean and median model index climatologies are really close to the observations, but 296 less in TiMCW, thereby confirming the results and analysis of Section 3.1.1. Therefore, in the 297 following, we focus on the evaluation of the models in ThSOW, more relevant. The models that better simulate the mean present-day SST seasonal cycle in the Iroise Sea are CNRM, ICHEC, HadCM3, MPI-MR and IPSL-MR. ICHEC, MPI-MR and CNRM have in common a higher ocean resolution and a more realistic topography and coastline geometry of the region of study than other models of the study; IPSL-MR, ICHEC and CNRM an higher atmospheric resolution. Regarding HadCM3, its good performance compared to HadGEM2-CC and HadGEM2-ES (the new generation of climate models of the MetOffice) is surprising also because the horizontal resolution has been refined in the recent ocean and atmosphere model versions. In the literature, Gordon et al. (2000) have demonstrated the very good skill of HadCM3 to simulate the SST with no flux adjustments, which was very novative at this time. By contrast, HadGEM2 (Collins et al., 2011) includes improvement designed to address specific systematic bias encountered in HadGEM1, namely Northern Hemisphere continental temperature biases, which may impact SST in the region of study. This result highlights the complexity of climate modelling in the fact that the realism of the simulations is not guaranteed to be improved by increasing the model resolution.

\subsubsection{Overview of Western English Channel}

314 English Channel are illustrated in Figure 4. Time series for 1980-2013 of monthly mean SST in the 315 satellite data (in ThSOW and in TiMCW) and in the CMIP5 models are produced for each of the seas 316 located around Brittany. For each time series representing the evolution of the SST in a particular month, a monthly trend is shown if significant. autumn season. This autumn trend is present in both ThSOW and TiMCW. It is stronger in ThSOW, and reaches the maximum value of about $0.6^{\circ} \mathrm{C} /$ decade --- which gives a SST increase of $1.8^{\circ} \mathrm{C}$ in 10 
32130 years --- in the Iroise Sea and in the Bay of Biscay. In spring, in ThSOW, we note also a 322 significant trend of about $+0.3^{\circ} \mathrm{C} /$ decade, this trend being more pronounced in the Iroise Sea. In 323 TiMCW, the entire water column has to be warmed, which leads to a lower ocean surface warming. In 324 summer, no significant trend can be detected, probably because of the higher interannual variability 325 during that season.

326 In CMIP5 models historical simulations, the observed warming trend is simulated. However, in the 327 Iroise Sea and in the English Channel, its seasonal distribution differs from the observed one. The 328 warming trend is found all over the year, except during summer, with smaller values of about $329 \quad 0.25^{\circ} \mathrm{C} /$ decade. In global models, the ocean surface warming trend seems more linearly linked to the 330 greenhouse gases radiative forcing, because of the poor simulation of continental shelf processes. As 331 pointed out by Holt et al. (2014) in their review paper, it is not just an issue of resolution: a suite of 332 specific dynamic processes act in regional seas, which along with their particular geographic setting act to shape the climatic impacts and lead to responses that may be di erent from the wider global ocean. Indeed, Adlandsvik (2008), in a marine downscaling experiment of the SRES-A1B scenario over the North Sea, has demonstrated that downscaling strengthen the surface ocean warming. The regional model has a more realistic shelf sea stratification, and most of the warming can be trapped in the surface mixed layer during the summer season, resulting in a better seasonal distribution. In our study, we highlight the need to refine in the same way the spatial resolution and to model tides in the Western English Channel.

On the other end, the Bay of Biscay has smaller tides so that the oceanic characteristics are better simulated in climate models. Accordingly, the modelled warming trend seasonal distribution is closer to that of satellite observations, albeit half. time series are shown in Figures 5 to 7, for the satellite observations averaged over the Iroise Sea, over the ThSOW and TiMCW areas, and for the median of the 13 CMIP5 simulations, with their 14 

between ThSOW and TiMCW in the Iroise Sea is highlighted, in particular in summer when the difference between the annual maxima reaches $2.5^{\circ}$ C. Time series of ThSOW and TiMCW are highly correlated, pointing out the driving role of atmospheric surface forcing.

In the right column are shown the index anomalies relative to each index time-mean over $1986^{-}$ 2005, this being the common period between observations and models. For the multi-model ensemble, anomalies are first calculated separately for each model, by removing the index time-mean of the model simulation, and then the median of the models anomalies is computed. That way, the bias between the different data sets is eliminated and clearer trends emerge in the CMIP5 multi-model ensemble. For the models, we note that trends of index absolute values and anomalies differ often by 15 to $30 \%$. Trends of anomalies, not affected by the bias between the models and thus more representative of the variability, are discussed.

The annual mean of the SST has a significant warming trend in observations and models (Fig. 5). It is slightly underestimated in models $\left(+0.2^{\circ} \mathrm{C} /\right.$ decade $)$ compared to the observations TiMCW $\left(+0.23^{\circ} \mathrm{C} /\right.$ decade $)$. These trends are in the range of previous estimates for the same period in the region, that is $\left[+0.2^{\circ} \mathrm{C} /\right.$ decade $+0.5^{\circ} \mathrm{C} /$ decade $]$ for observed SST (Cannaby and Hüsrevoglu, 2009, Michel et al., 2009, Smyth et al., 2010, Saulquin and Gohin, 2010, Holt et al., 2012) and $\left[+0.175^{\circ} \mathrm{C} /\right.$ decade $+0.3^{\circ} \mathrm{C} /$ decade $]$ for modelled SST (Michel et al., 2009, Holt et al., 2012). The underestimation of the SST trend in models compared to satellite data has also been observed by Michel et al. (2009) in a regional modelling study of the Bay of Biscay, in spite of the higher resolution of their simulation (about $20 \mathrm{~km}$ ). Their SST trend is of $+0.22^{\circ} \mathrm{C} /$ decade in the model versus $+0.37^{\circ} \mathrm{C} /$ decade in satellite data, over a domain ranging up to $15^{\circ} \mathrm{W}$ into the open ocean. other indices do not show significant trend. In ThSOW, the date of the autumn onset is also delayed by 4 day/decade, certainly related to the strong autumn temperature increase of $+0.48^{\circ} \mathrm{C} /$ decade. 
The warming is there also fairly strong in spring $\left(+0.3^{\circ} \mathrm{C} /\right.$ decade $)$. that of the annual minimum $\left(+0.19^{\circ} \mathrm{C} /\right.$ decade $)$, resulting in an increase of the annual SST amplitude. The annual maximum increase is not detected in the time series of indice I3 absolute value (Fig. 5, left column) because of the large inter-model dispersion for summer temperatures. There is no significant or a too weak trend in the time series of indices I5 to I8 (Fig. 6), that characterize a possible seasonal shift. Indeed, models present a constant warming over all seasons of about $+0.21^{\circ} \mathrm{C} /$ decade, with no significant seasonal shift. natural climate variability and anthropogenic climate change to conclude on warming trends related to climate change. Nevertheless, whereas it is clear that there is a significant multidecadal pattern in the factors to the recent observed warming (Knight et al., 2005, Cannaby and Hüsrevoğlu, 2009, Swanson et al., 2009, Ting et al., 2009). In our study, trends are computed over a relatively short period (28 years in the observations) compared to the 60 years cycle of the Atlantic Multi-decadal Oscillation (AMO) natural variability pattern observed over the North Atlantic (Knight et al., 2005). The latter is characterized by a SST increase over 1980-2007, followed by a decrease up to 2013. Cannaby and Hüsrevoglu (2009) have shown that under the AMO warming phase, the AMO variability is responsible for $50 \%$ of the warming trend on the northwestern European coast. If a too short period is considered, the trend should rather be attributable to AMO natural variability than to anthropogenic climate change, as in Tréguer et al. (2014), wherein a not really significant slightly negative trend was estimated over the period 1998-2012 in the coastal area of Iroise Sea. Saulquin and Gohin (2010), using the same AVHRR-SST satellite data as this study over the period 1986-2006, found identical spatial distribution of the SST trend with slightly larger values of $+0.4^{\circ} \mathrm{C} /$ decade in TiMCW to $+0.5^{\circ} \mathrm{C} /$ decade in ThSOW. As the period we consider extends up to 2013 and thus contains both a 
warming and a cooling phase of the AMO natural variability cycle, it explains the slight trend overestimation in Saulquin and Gohin (2010) and gives more confidence to the trend values of our study as being for a major part attributable to anthopogenic climate change. simulated by the CMIP5 multi-model ensemble (Section 3.1). Over the last 30 years, the annual mean warming is slightly underestimated in models, with an evenly distribution throughout the year and no seasonal shift; whereas observations show a seasonal shift due to a strong autumn warming, less noticeable in the rest of the year (Section 3.2). from the 5th IPCC future scenarios projections to evaluate the future SST evolution in the Iroise Sea. are estimated from the projections carried out in CMIP5 for the scenarios established in the 5th IPCC report (IPCC, 2014). Figure 8 (resp. 9) shows time series of indices I1 to I4 (resp. seasonal indices I10 to I13) for the 13 CMIP5 multi-model ensemble median, over 1980-2004 for historical simulations and 2005-2100 for the scenarios RCP2.6, RCP4.5 and RCP8.5 (described in Section 2.1). Anomalies of indices relative to the time-mean over 1986-2004 are plotted, as in the left column of Figures 5 to 7. Fits to second order polynomial functions are superimposed. for the RCP8.5 one in year 2100. The uncertainty linked to the scenarios, of about $1.5^{\circ} \mathrm{C}$ for the winter minimum, is half that of the summer maximum. In the scenario RCP2.6, the annual mean and summer SST increase up to around 2060 and then decline. It is consistent with the radiative forcing evolution (Van Vuuren et al., 2011), but with a time-lag of 10 to 20 years. In year 2100, seasonal means converge to a constant warming all year round of $+0.5^{\circ} \mathrm{C}$. In the scenario $\mathrm{RCP} 4.5$, we note an 
424 increase followed by a stabilization of the SST around year 2080, again with a time-lag of 10 to 20

425 years with respect to the imposed radiative forcing. At year 2100, the annual mean is forecast to reach

$426+1^{\circ} \mathrm{C}$ with a seasonal range of $\left[+0.8^{\circ} \mathrm{C}+1.5^{\circ} \mathrm{C}\right]$. In the scenario RCP8.5, a high rate of surface 427 temperature increase follows the radiative forcing, reaching $+2.5^{\circ} \mathrm{C}$ for the annual mean with a

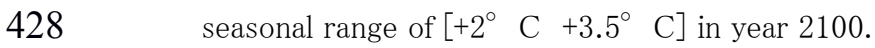

429 For all scenarios, the warming is more moderate in winter-spring and stronger in summer430 autumn (Fig. 9). The warming difference between winter and summer is also highlighted in regional 431 downscaled projections over the North Sea (Adlandsvik, 2008), the western European continental shelf 432 (Holt et al., 2010) and the Irish Sea (Olbert et al., 2012). Holt et al. (2010), analyzing the SST and 433 hydrography changes by the end of the century in a downscaling study including our study region, 434 associated the SST changes to increasing summer stratification. From a regional perspective, a 435 comparison between our results and that of the latter study is interesting, although somewhat tricky 436 because different scenarios are simulated. In scenario SRES-A1B, Holt et al. (2010) simulate an increase of the Iroise Sea SST of about $+2.5^{\circ} \mathrm{C}$ in winter to $+3.5^{\circ} \mathrm{C}$ in autumn. The scenario SRES$\mathrm{A} 1 \mathrm{~B}$ is close to the scenario RCP6.0, with a radiative forcing increase between scenarios RCP4.5 and RCP8.5. In our study, the range between scenarios RCP4.5 and RCP8.5 gives an increase of $\left[+0.8^{\circ} \mathrm{C}\right.$

$\left.440+2^{\circ} \mathrm{C}\right]$ in winter to $\left[+1.3^{\circ} \mathrm{C}+3^{\circ} \mathrm{C}\right]$ in summer. Thus, the warming on the shelf seems 441 underestimated in global climate models, especially in summer-autumn, due to a poor simulation of 442 physical and hydrographical processes specific to the oceanic shelves in Brittany.

444 and extremes. Indeed, climate change is likely to be associated with an increase of the occurence of 445 extreme events (IPCC, 2014), linked to a modification of the statistical distribution of the climate 446 variables. Changes in the shape of the probability distribution of SST may contribute as much to changes in extremes as a shift of mean temperatures (Schaeffer et al., 2005). To evaluate the changes

448 in mean seasonal SST extremes, the probability distribution functions (PDF) of the winter and summer 449 mean SST in CMIP5 multi-model ensemble are represented in Figure 10 for the present-day climate 

variability are negligible compared to changes in interannual variability (not shown). In the near-future, a similar increase of SST characteristics (mean and variance) is simulated in all three scenarios for both seasons. In the far-future, the SST variance increases in the three scenarios, associated with an additional increase in the mean SST in scenarios RCP4.5 and RCP8.5. The increase of the mean SST is correlated with an increase of its variance and tail and thus of the probability in the occurrence of extreme temperatures. In all periods, the variance of the SST is larger in summer than in winter. All these projected changes in the SST mean seasonal cycle and interannual variability, more intense in summer, may impact critically marine ecosystems.

\section{Conclusion}

In this study, previous and projected SST seasonal changes have been estimated in the Iroise Sea from satellite data and CMIP5 multi-model ensemble. To this end, a set of indices has been developed to characterize the change of SST, focusing particularly on the seasonal cycle and its modification. Here, the benefit of these indices to estimate warming trends in the SST seasonal cycle is highlighted in the Iroise Sea. This new approach can be applied to any ocean region of the world.

We first evaluated SST seasonal changes in the previous decades within the study area, using high-resolution satellite observations. In the Iroise Sea, a significant warming trend is concentrated in the autumn season. It is not significant in summer, albeit visible in the observations, because of the large interannual variability during this season. The autumn trend is stronger offshore, with a SST annual mean increase of $0.32^{\circ} \mathrm{C} /$ decade, but weaker in coastal waters $\left(0.23^{\circ} \mathrm{C} /\right.$ decade $)$, where a strong vertical mixing induced by tides and winds acts to reduce surface warming. Then, the performance of an ensemble of CMIP5 climate models in simulating recent seasonal changes of SST in the region is estimated. Because of their low resolution, CMIP5 global simulations are rarely used to evaluate SST changes at regional scale. Yet, our study highlights they may provide a first order estimate of SST seasonal cycle climatology under present and future climate conditions. Indeed, the median of CMIP5 models reproduces very well the observed SST mean seasonal cycle in off-shore 
476 waters. It is less proficient in regions closer to the coast, due to model coarse resolution and the

477 absence of tidal processes. The trend of the annual mean SST is relatively well simulated, albeit

478 somewhat underestimated $\left(0.20^{\circ} \mathrm{C} /\right.$ decade $)$ and evenly distributed throughout the year. This

479 assessment of CMIP5 models skill to reproduce the observed recent SST changes gives confidence in

480 future change estimates from CMIP5 models simulations in the off-shore seas of the Western English

$481 \quad$ Channel.

482 In this study, estimate of SST future warming related to anthropogenic climate is given for the 483 Iroise Sea, where the annual mean SST increase ranges from $0.5^{\circ} \mathrm{C}(\mathrm{RCP} 2.6)$ to $2.5^{\circ} \mathrm{C}(\mathrm{RCP} 8.5)$ by 484 year 2100, with a seasonal modulation leading to a more intense warming in summer-autumn than in 485 winter-spring. The simulated future evolution of the SST trend, with larger values in summer-autumn 486 than in winter-spring is consistent with seasonal variations of the observed trend in the previous 487 decades. The increase of the mean SST is correlated to an increase of its variance and interannual 488 variability and thus of the probability in the occurrence of extreme temperatures, mostly in summer.

Nevertheless, in this region, significant differences have been highlighted in the previous decades from satellite observations in the warming intensity and seasonal distribution between ThSOW, located offshore from the Ushant front, and TiMCW. In the ThSOW, the observed warming trend is $+0.32^{\circ} \mathrm{C} /$ decade over the last 30 years, while it is $+0.23^{\circ} \mathrm{C} /$ decade in the TiMCW. Nevertheless, 493 due to their poor resolution (among other factors), CMIP5 global climate models cannot simulate SST 494 changes in coastal areas of the Iroise Sea. Thus, we highlight the need to refine resolution in the ocean 495 and to include tides to better simulate the mesoscale dynamics and changes. An increase of seasonal 496 variability due to marine downscaling was observed in Adlandsvik (2008), but with a regional ocean model covering only the North Sea. Higher resolution in the atmosphere may also improve the realism of the simulations, as demonstrated by Muller et al. (2007) in a high-resolution ( $6 \mathrm{~km})$ simulation of the Iroise Sea with the regional ocean model MARS, forced by atmospheric fields downscalled at the same resolution. They shown that a better constrained and higher resolution atmospheric forcing 
502 further and address the issue of uncertainty, an ensemble of coupled ocean-atmosphere regional 503 simulations could be performed over the northwestern European continental shelf, driven by a set of 504 CMIP5 global climate model under historical conditions and then RCP scenarios to cover the period $505 \quad 1980-2100$.

Regarding environmental impacts in the Western English Channel, the predicted increase in SST may strongly affect marine biology, particularly algae biomass and phenology. Increase in temperature may be responsible for more frequent occurrences of Harmful Algal Blooms (HAB) in the Western English Channel waters. Using a modelling approach associating the IPSL-CM4 global climate model future projection under the SRES-A1B scenario and the regional oceanographic-biogeochemical model POLCOMS-ERSEM over the Northwestern European shelf, Glibert et al. (2014) have projected an expansion in area and number of months annually conducive to development of pelagic Prorocentrum and Karenia HABs along the Northwestern European Shelf system by 2100. Moreover, a possible shift of the thermal front where this species thrives towards shallower waters would have more dramatic effects on the benthic fauna, including exploited shellfish (e.g. oysters, scallops).

The impacts of the SST increase on the evolution of the kelp forest in Northern Brittany have been highlighted by Meleder et al. (2010), going to a possible complete extinction in the area. The 518 distribution of kelp Laminaria digitata ranges from the Southern Brittany to Norway with an optimum range of temperature between $10^{\circ} \mathrm{C}$ and $15^{\circ} \mathrm{C}$ and a reproduction impaired above $18^{\circ} \mathrm{C}$. Raybaud et al. (2013) show that Laminaria digitata could disappear from the coast of France as early as the 2050s, using MPI-ESM-LR and CNRM-CM5 CMIP5 models and three RCP scenarios (RCP2.6, RCP4.5 and RCP8.5). It is likely that a delay will be observed in the mixed coastal waters of Northern Brittany, that are not explicitly represented in the latter global climate models. In these coastal waters, we expect a slower increase in temperature. Changes in Laminaria digitata and more importantly the forest-forming Laminaria hyperboles (Smale et al., 2013) would have profound consequences for the ecosystems of the English Channel and Southern North Sea ; although some replacement would occur from the warm-water species Laminaria ochreleuca. 

fluctuations like the AMO (Mieszkowska et al., 2014) and climate change (Southward et al 1995; Herbert et al 2003 ; Hawkins et al 2008 ; Philippart et al., 2011) in the Channel region have mainly warming of all the water column. This migration of the species has implications for fisheries. Genner et al. (2004, 2010) shows that climate change and particularly sea surface temperature change has dramatic effects on marine fish community composition and abundance, especially for small species less impacted by overharvesting. Going back to the Middle Ages, Southward et al. (1988) demonstrate the impact of sea temperature on fluctuations in herring and pilchard fisheries.

\section{Acknowledgments}

This work has been funded by the Belmont Forum International Opportunity Fund, in the framework of the project ARTISTICC (Adaptation Research a Transdisciplinary Community and Policy Centred Approach). We acknowledge the World Climate Research Program's Working Group on Coupled Modelling, which is responsible for CMIP, and we thank the climate modeling groups (listed in Table 1 of this paper) for producing and making available their model output. For CMIP the U.S. Department of Energy's Program for Climate Model Diagnosis and Intercomparison provides coordinating support and led development of software infrastructure in partnership with the Global Organization for Earth System Science Portals. We acknowledge Ifremer for providing its satellitederived SST data set; the Met Office for the OSTIA data set and MyOcean for the ODYSSEA data set. 


\section{List of tables and figures}

Tab. 1 CMIP5 climate models used in the study. Name, resolution of the ocean model, and characteristics of its horizontal grid around Brittany.

Tab. 2 Presentation of indices. Characteristics, number, definition, computing methodology.

Fig. 1 Snapshot of the SST on 18th June 2003 from Ifremer satellite-derived data. Selected ThSOW and TiMCW areas in the Iroise Sea, the English Channel and the Bay of Biscay (solid line). A typical grid cell size for CMIP5 models (dashed line), representative of the grid cell size of 10 models over the 13 models of the study.

Fig. 2 Mean annual cycle of SST: ensemble median (solid) and mean (dashed) of 13 CMIP5 models (black) as well as satellite data spatial mean over ThSOW (green) and TiMCW (red), averaged over 1980-04 for CMIP5 and 1986-13 for satellite data. The shading indicates the interquartile ensemble spread (range between the 25th and 75th quantiles).

Fig. 3 The "portrait" diagram of relative errors in the 1986-2004 climatologies of SST indices in Iroise Sea simulated by the CMIP5 models with respect to the satellite data: (a) TiMCW and (b) ThSOW.

Fig. 4 Time series of monthly mean SST from 1980 to 2013 of the CMIP5 median (black), spatial mean of satellite data over ThSOW (green) and TiMCW (red) in the Iroise Sea, the English channel and the Bay of Biscay. The shading indicates the interquartile ensemble spread (range between the 25th and 75th quantiles). Trends statistically significant at 95\% confidence level are superimposed.

Fig. 5 I1 to I4 SST indices in the Iroise Sea from 1980 to 2013. For the respective index, the left column displays absolute values of the CMIP5 median (bold black) and of the spatial mean of the satellite data (grey) over the Iroise Sea, with their associated trends. The satellite data average over the ThSOW (green) and TiMCW (red) are superimposed in dashed line. The right column shows anomalies with respect to the common period 1986-2004 of the CMIP5 median (black) and of satellite data spatial mean over ThSOW (green) and TiMCW (red). The shading indicates the interquartile 2: 

significant at $95 \%$ confidence level are superimposed.

Fig. 6 I5 to I9 SST indices in the Iroise Sea from 1980 to 2013. For the respective index, the left column displays absolute values of the CMIP5 median (bold black) and of the spatial mean of the satellite data (grey) over the Iroise Sea, with their associated trends. The satellite data average over the ThSOW (green) and TiMCW (red) are superimposed in dashed line. The right column shows anomalies with respect to the common period 1986-2004 of the CMIP5 median (black) and of satellite data spatial mean over ThSOW (green) and TiMCW (red). The shading indicates the interquartile ensemble spread of CMIP5 models (range between the 25th and 75th quantiles). Trends statistically significant at $95 \%$ confidence level are superimposed.

Fig. 7 I10 to I13 SST indices in the Iroise Sea from 1980 to 2013. For the respective index, the left column displays absolute values of the CMIP5 median (bold black) and of the spatial mean of the satellite data (grey) over the Iroise Sea, with their associated trends. The satellite data average over the ThSOW (green) and TiMCW (red) are superimposed in dashed line. The right column shows anomalies with respect to the common period 1986-2004 of the CMIP5 median (black) and of satellite data spatial mean over ThSOW (green) and TiMCW (red). The shading indicates the interquartile ensemble spread of CMIP5 models (range between the 25th and 75th quantiles). Trends statistically significant at $95 \%$ confidence level are superimposed.

Fig. 8 I1 to I4 SST indices in the Iroise Sea: for the median of the historical CMIP5 simulations during 1980-2004 (black), for satellite data spatial mean over ThSOW during 1986-2013 (grey), for the median of the CMIP5 future projections over 2005-2100 in the RCP2.6 (green; scenario designed to meet the $2^{\circ} \mathrm{C}$ global average warming target compared to pre-industrial conditions by 2100), RCP4.5 (red; where radiatine forcing peaks at about $4.5 \mathrm{~W} / \mathrm{m} 2$ in year 2100) and RCP8.5 (blue; 601 shading indicates the interquartile ensemble spread (range between the 25th and 75th quantiles). 602 Indice anomalies relative to the time-mean over 1986-2004 are plotted. Fits to second order 
603 polynomial functions are superimposed.

604

605

606

607

608

609

610

611

612

613

614

615

616
Fig. 9 I10 to I13 SST indices in the Iroise Sea: for the median of the historical CMIP5 simulations during 1980-2004 (black), for satellite data spatial mean over ThSOW during 1986-2013 (grey), for the median of the CMIP5 future projections over 2005-2100 in the RCP2.6 (green; scenario designed to meet the $2^{\circ} \mathrm{C}$ global average warming target compared to pre-industrial conditions by 2100), RCP4.5 (red; where radiatine forcing peaks at about $4.5 \mathrm{~W} / \mathrm{m} 2$ in year 2100) and RCP8.5 (blue; assuming a high rate of radiative forcing increase, peaking at $8.5 \mathrm{~W} / \mathrm{m} 2$ in year 2100) scenarios. The shading indicates the interquartile ensemble spread (range between the 25th and 75th quantiles). Indice anomalies relative to the time-mean over 1986-2004 are plotted. Fits to second order polynomial functions are superimposed.

Fig. 10 Probability distribution function (pdf) of the winter (top panels) and summer (bottom panels) means over 1986-2004 for CMIP5 historical simulations (black), for satellite data spatial mean in the Iroise Sea ThSOW (grey); and over 2031-2050 (left panels) and 2081-2100 (right panels) for CMIP5 future projections in the RCP2.6 (green), RCP4.5 (red) and RCP8.5 (blue) scenarios. 


\section{References}

618

619

620

621

622

623

624

625

626

627

628

629

630

631

632

633

634

635

636

637

638

639

640

Ådlandsvik B. 2008. Marine Downscaling of a Future Climate Scenario for the North Sea. Tellus 60A:451-458.

Altizer S, Ostfeld RS, Johnson PTJ, Kutz S and Harvel CD. 2013. Climate change and infectious deseases: from evidence to a predictive framework. Science 341: 514-519.

Autret E, Piolle J-F. 2011. Product User Manual for ODYSSEA Level 3 and 4 Global and Regional Products. MYO-PUM-SST-TAC-ODYSSEA, Ifremer/CERSAT.

Bellard C, Bertelsmeier C, Leadley P, Thuiller W and Courchamp F. 2012. Impacts of climate change on the future of biodiversity. Ecology Letters 15: 365-377.

Bissinger JE, Montagnes DJS, Sharples J, Atkinson D. 2008. Predicting marine phytoplankton maximum growth rates from temperature: improving on the Eppley curve using quantile regression. Limnology and Oceanography 53 (2) :487-493.

Cambon G. 2008. Étude numérique de la mer d’Iroise: Dynamique, variabilité du front d'Ouessant et évaluation des échanges cross-frontaux. Ph.D. thesis, Univ. de Bretagne Occident., Brest, France.

Cannaby H and Hüsrevoğlu YS. 2009. The influence of low-frequency variability and long-term trends in North Atlantic sea surface temperature on Irish waters. ICES Journal of Marine Science 66 : 1480-1489.

Chelton DB and SP Xie. 2010. Coupled ocean-atmosphere interaction at oceanic mesoscales. Oceanography Magazine, 23:52-69.

Chen B .2015. Patterns of thermal limits of phytoplankton. Journal of Plankton Research, doi :10.1093/plankt/fbv009.

Collins WJ et al. 2011. Development and evaluation of an Earth-System model HadGEM2. Geosci. Model Dev., 4, 1051-1075, doi:10.5194/gmd-4-1051-2011.

Dong BW, Sutton RT. 2005. Mechanism of interdecadal thermohaline circulation variability in a 26 
coupled ocean-atmosphere GCM. J. Clim, $18: 1117-1135$.

642

Donlon CJ, Martin M, Stark JD, Roberts-Jones J, Fiedler E, Wimmer W. 2011. The operational

643 sea surface temperature and sea ice analysis (OSTIA) system. Rem. Sens. Environ., http://dx.doi.org/10.1016/j.rse.2010.10.017.

Dye SR, Hughes SL, Tinker J, Berry DI, Holliday NP, Kent EC, Kennington K, Inall M, Smyth T, Nolan G, Lyons K, Andres O and Beszczynska-Möller A. 2013. Impacts of climate change on temperature (air and sea). MCCIP Science Review 2013, 1-12. doi:10.14465/2013.arc01.001-012. Air Temperature in the Northern Hemisphere. Advances in Atm. Sciences 20:1-16.

Esnaola G, Sáenz J, Zorita E, Lazure P, Ganzedo U, Fontán A, Ibarra-Berastegi G and A Ezcurra. 2012. Coupled air-sea interaction patterns and surface heat-flux feedback in the Bay of Biscay. J. Geophys. Res. 117:C06030, doi:10.1029/2011JC007692.

Foley AM. 2010. Uncertainty in regional climate modelling: A review. Progress in Physical Geography. doi: 10.1177/0309133310375654.

Friocourt YF, Skogen MD, Stolte W and Albretsen J. 2012. Marine downscaling of a future climate scenario in the North Sea and possible effects on dinoflagellate harmful algal blooms. Food Additives \& Contaminants: Part A, 29:1630-1646. doi:10.1080/19440049.2012.714079.

British marine fish. Proc R Soc B, 271: 655-61. 
Geophys. Res. 113:2156-2202, DOI: 10.1029/2007JD008972.

Glibert P M, JI Allen, Y Artioli, A Beusen, L Bouwman, J Harle, R Holmes and J Holt .2014. Vulnerability of coastal ecosystems to changes in harmful algal bloom distribution in response to climate change: projections based on model analysis. Global Change Biology 20(12):3845-58. doi: $10.1111 /$ gcb. 12662 .

Gohin F, P Bryère, J Griffiths. 2015. The exceptional surface turbidity of the North-West European shelf seas during the stormy 2013-2014 winter: consequences for the initiation of the phytoplankton blooms? Journal of Marine Systems. 148:70-85. doi:10.1016/j.jmarsys.2015.02.001. simulation of SST, sea ice extent and ocean heat transports in a version of the Hadley Centre coupled model without flux adjustments. Climate Dynamics 16 : 147-168. doi:10.1007/s003820050010. climate warming: implications for open ocean - shelf exchange, primary production, and carbon absorption. Biogeosciences 10:3767-3792, doi:10.5194/bg-10-3767-2013. hydrographic parameters, measured from a ship of opportunity, in bloom formation of Karenia mikimotoi in the English Channel. Journal of Marine Systems 140:39-49, doi:10.1016/j.jmarsys.2014.07.001.

Hawkins SJ, Southward AJ, Genner MJ 2003. Detection of environmental change in a marine Genner MJ \& Southward AJ 2008. Complex interactions in a rapidly changing world: responses of rocky shore communities to recent climate change, Climate Research, 37:123 - 133. 

implications for climate change. Ecological monographs 76(4): 461-479. the impact of oceano-climatic changes on marine ecosystems using a multivariate index : the case of the Bay of Biscay (North Atlantic-European Ocean). Global Change Biology 14 (1):27-38. DOI : 10.1111/j.1365-2486.2007.01471.x

Hjollo S, MD Skogen, E Svendsen. 2009. Exploring currents and heat within the North Sea using a numerical model. Journal of Marine Systems 78(1):180-192, DOI: 10.1016/j.jmarsys.2009.06.001.

ter Hofstede R, Hiddink JG, Rijnsdorp AD. 2010. Regional warming changes fish species richness in the eastern North Atlantic Ocean. Mar. Ecol. Prog. Ser. 414:1-9, doi: 10.3354/meps08753.

Hogg, A.McC., W.K. Dewar, P. Berloff, S. Kravtsov, and D.K. Hutchinson. 2009. The effects of mesoscale ocean-atmosphere coupling on the large-scale ocean circulation. Journal of Climate 22:4,066-4,082.

Holt J, Harle J, Proctor R, Michel S, Ashworth M, Batstone C, Allen I, Holmes R, Smyth T, Haines K, Bretherton D, Smith G. 2009. Modelling the global coastal ocean. Philosophical Transactions of the Royal Society A: Mathematical, Physical and Engineering Sciences 367 (1890):939-951. doi:10.1098/rsta.2008.0210.

Holt J, S Wakelin, J Lowe and J Tinker. 2010. The potential impacts of climate change on the 712 hydrography of the northwest European continental shelf. Progress In Oceanography 86 (3-4):361713 379, doi:10.1016/j.pocean.2010.05.003. 
715 variability and trends in the temperature of the northwest European continental shelf: A model-data

716 synthesis. Progress in Oceanography 106:96-117. doi:10.1016/j.pocean.2012.08.001.

717 Holt $\mathrm{J}$ et al. 2014. Challenges in integrative approaches to modelling the marine ecosystems of the

718 North Atlantic: Physics to Fish and Coasts to Ocean. Progress in Oceanography

719 doi:10.1016/j.pocean.2014.04.024.

720

721

722

723

724

725

726

727

728

729

730

731

732

733

734

735

736

737

738

739
IPCC. 2007. Climate Change 2007: Synthesis Report. Contribution of Working Groups I, II and III to the Fourth Assessment Report of the Intergovernmental Panel on Climate Change. Core Writing Team, Pachauri, R.K. and Reisinger, A. (Eds.) IPCC, Geneva, Switzerland, pp 104.

IPCC. 2014. Climate Change 2014: Impacts, Adaptation, and Vulnerability. Part B: Regional Aspects. Contribution of Working Group II to the Fifth Assessment Report of the Intergovernmental Panel on Climate Change [Barros, V.R., C.B. Field, D.J. Dokken, M.D. Mastrandrea, K.J. Mach, T.E. Bilir, M. Chatterjee, K.L. Ebi, Y.O. Estrada, R.C. Genova, B. Girma, E.S. Kissel, A.N. Levy, S. MacCracken, P.R. Mastrandrea, and L.L. White (eds.)]. Cambridge University Press, Cambridge, United Kingdom and New York, NY, USA, 688 pp.

Karl T, and D Easterling. 1999. Climate extremes: Selected review and future research directions. Clim. Chang. 42:309-325.

Klein Tank AG, FW Zwiers and X Zhang. 2009. Guidelines on analysis of extremes in a changing climate in support of informed decisions for adaptation. Climate data and monitoring WCDMP-No. 72, WMO-TD No. 1500, 56 pp.

Knight JR, RJ Allan, CK Folland, M Vellinga, and ME Mann. 2005. A signature of persistent natural thermohaline circulation cycles in observed climate. Geophys. Res. Lett. 32, L20708, doi:10.1029/2005GL024233.

Lazure P, Garnier V, Dumas F, Herry C, Chifflet M. 2009. Development of a hydrodynamic model of the Bay of Biscay. Validation of hydrology. Continental Shelf Research 29(8):985-997, http://dx.doi.org/10.1016/j.csr.2008.12.017.

30 

doi:10.1016/j.csr.2008.12.020. Res. 4 (6):637-660. seabed habitats - Case study of subtidal kelp forests on the coast of Brittany, France. Marine Biology 157: 1525-1541. doi:10.1007/s00227-010-1426-4. Sea (1948-2007) derived from a multidecadal hindcast. Journal of Marine Systems 86(3-4):35-44. doi:10.1016/j.jmarsys.2011.02.001.

Michel S, Treguier A-M, Vandermeirsch F .2009. Temperature variability in the Bay of Biscay during the past 40 years, from an in situ analysis and a 3D global simulation. Continental Shelf Research 29(8):1070-1087. http://dx.doi.org/10.1016/j.csr.2008.11.019 occuring intertidal barnacles Semibalanus balanoides and Chthamalus spp. linked to the Atlantic Multidecadal Oscillation. Journal of Marine Systems 133: 70-76.

Millennium Ecosystem Assessment. 2005. Ecosystems and Human Well-being: Synthesis. Island Press, Washington, DC.

Moss RH et al. 2010. The next generation of scenarios for climate change research and assessment. Nature 463:747-756, doi:10.1038/nature08823. regional oceanic model: the Iroise Sea. Ocean Dynamics 57(4-5) :375-400, doi :10.1007/s10236-0070115-4. 

Working Group III of the Intergovernmental Panel on Climate Change. Cambridge University Press, Cambridge, UK and New York, NY, USA. climate changes in the Irish Sea. Cont. Shelf. Res. 41:48-60. O’Sullivan G, Reid PC 2011. Impacts of climate change on European marine ecosystems: observations, expectations and indicators. J. Exp. Mar. Biol. Ecol., 400. Geophys. Res. 83:4615-4622 populations of competing species to climate change. Ecology, 89(11): 3138-3149.

Raybaud V, G Beaugrand, E Goberville, G Delebecq, C Destombe, M Valero et al. 2013. Decline in Kelp in West Europe and Climate. PLOS ONE 8(6). doi:10.1371/journal.pone.0066044

Rhein M et al. 2013. Observations: Ocean (Chapter 3). In: Climate Change 2013: The Physical Science Basis. Contribution of Working Group I to the Fifth Assessment Report of the Intergovernmental Panel on Climate Change [Stocker, T. (eds.)]. Cambridge University Press, Cambridge, United Kingdom and New-York, NY, USA, 255-315. doi:10.1017/CBO9781107415324.010. 2011. RCP-8.5: Exploring the consequence of high emission trajectories. Climatic Change 109, Issue 1-2, doi:10.1007/s10584-011-0149-y. 
Research 18:31-37.

Sharples J, Holt J and Dye SR. 2013. Impacts of climate change on shelf sea stratification. MCCIP Science Review 2013 67-70, doi:10.14465/2013.arc08.067-070.

Sillmann J, VV Kharin, X Zhang, FW Zwiers, and D Bronaugh. 2013. Climate extremes indices in the CMIP5 multi-model ensemble: Part 1. Model evaluation in the present climate. J. Geophys. Res. Atmos. 118:1716-1733, doi:10.1002/jgrd.50203.

Simpson JH, CM Allen and NC Morris. 1978. Fronts on the continental shelf. J. Geophys. Res. 83(C9):4607-4614.

Smale DA, Burrows M, Moore P, O’Connor N and Hawkins S. 2013. Threats and knowledge gaps Evolution, 3: 4016-4038.

Smyth TJ, JR Fishwick, L Al-Moosawi, DG Cummings, C Harris, V Kitidis, A Rees, V MartinezVicente and E Woodward. 2010. A broad spatio-temporal view of the Western English Channel Observatory. J. Plankton Res. 32 (5): 585-601. doi: 10.1093/plankt/fbp128. 366, doi:10.1038/285361a0.

Southward AJ, Boalch GT, Maddock L. 1988. Fluctuations in the herring and pilchard fisheries of Devon and Cornwall linked to change in climate since the 16thcentury. J Mar Biol Ass, 68: 423-445.

Southward AJ, SJ Hawkins and MT Burrows. 1995. 70 years observations of changes in distribution and abundance of zooplankton and intertidal organisms in the western English Channel in

810 relation to rising sea temperature. Journal of Thermal Biology, 20: 127-155. 
814 climate change. Proceedings of the National Academy of Sciences of the United States of America.

$815 \quad 106: 16120-16123$.

Taylor KE, RJ Stouffer and GA Meehl. 2012. An overview of CMIP5 and the experiment design. Bull. Am. Meteorol. Soc. 93(4):485-498, doi:10.1175/BAMS-D-11-00094.1. change and climate-driven invasion of the Pacific Oyster (Crassostrea gigas) along European coasts: a bioenergetics modelling approach. Journal of Biogeography 43:568-579. B, Wise MA, Clarke LE, Edmonds JA. 2011. RCP4.5: A pathway for stabilization of radiative forcing by 2100. Climatic Change 109, Issue 1-2, doi:10.1007/s10584-011-0151-4.

Ting M, Kushnir Y, Seager R, Li C. 2009. Forced and internal twentieth-century SST trends in the North Atlantic. J. Climate 22:1469-81, DOI: 10.1175/2008JCLI2561.1.

Treguer P, E Goberville, N Barrier, S L’Helguen, P Morin, Y Bozec, P Rimmelin-Maury, M 827 Czamanski, E Grossteffan, T Cariou, M Repecaud, L Quemener . 2014. Large and local-scale 828 influences on physical and chemical characteristics of coastal waters of Western Europe during winter. 829 Journal of Marine Systems 139: 79-90. http://dx.doi.org/10.1016/j.jmarsys.2014.05.01 Ecological Modelling 210(4):351-376. doi:10.1016/j.ecolmodel.2007.08.025 
838 Wyrtki K. 1965. The annual and semiannual variation of Sea Surface Temperature in the North 839 Pacific Ocean. Limnology and Oceanography $10: 307-313$.

Young EF and JT Holt. 2007. Prediction and analysis of long-term variability of temperature and salinity in the Irish Sea. Journal of Geophysical Research 112 (C1). doi:C01008. 10.1029/2005JC003386. Canada during the 20th century. Atmos. Ocean 38:395-429. 


\begin{tabular}{|c|c|c|c|c|c|c|}
\hline climate model & Institute & ocean model & $\begin{array}{l}\text { ocean model } \\
\text { resolution }\end{array}$ & $\begin{array}{l}\text { atmospheric } \\
\text { model }\end{array}$ & $\begin{array}{l}\text { atmospheric } \\
\text { model resolution }\end{array}$ & $\begin{array}{l}\text { grid topography around } \\
\text { Brittany }\end{array}$ \\
\hline IPSL-LR & IPSL, France & NEMO-ORCA2 & $2^{\circ} \times 2^{\circ}$ & LMDz & $1.875^{\circ} \times 3.75^{\circ}$ & $\begin{array}{l}\text { No English Channel, } \\
\text { England and Ireland are } \\
\text { connected to the continent. }\end{array}$ \\
\hline IPSL-MR & IPSL, France & NEMO-ORCA2 & $2^{\circ} \times 2^{\circ}$ & LMDz & $1.25^{\circ} \times 2.5^{\circ}$ & $\begin{array}{l}\text { No English Channel, } \\
\text { England and Ireland are } \\
\text { connected to the continent. }\end{array}$ \\
\hline CNRM-CM5 & CNRM, France & NEMO-ORCA1 & $1^{\circ} \times 1^{\circ}$ & Arpege-Climate & $1.4^{\circ} \times 1.4^{\circ}$ & realistic \\
\hline $\begin{array}{l}\text { ICHEC } \\
\text { EC-EARTH }\end{array}$ & $\begin{array}{l}\text { European } \\
\text { consortium (29 } \\
\text { institutes) }\end{array}$ & NEMO-ORCA1 & $1^{\circ} \times 1^{\circ}$ & IFS & $1.125^{\circ} \times 1.125^{\circ}$ & realistic \\
\hline Had-CM3 & $\begin{array}{l}\text { Met Office } \\
\text { Hadley center, } \\
\text { England }\end{array}$ & HadOM3 & $1.25^{\circ} \times 1.25^{\circ}$ & HadAM3 & $2.45^{\circ} \times 3.75^{\circ}$ & $\begin{array}{l}\text { No English Channel, } \\
\text { England and Ireland are } \\
\text { connected to the continent. } \\
\text { No breton tip. }\end{array}$ \\
\hline HadGEM2-CC & $\begin{array}{l}\text { Met Office } \\
\text { Hadley center, } \\
\text { England }\end{array}$ & HadGOM2 & $0.3^{\circ}-1^{\circ} \times 1^{\circ}$ & HadGAM2 & $1.25^{\circ} \times 1.875^{\circ}$ & $\begin{array}{l}\text { No English Channel, } \\
\text { England and Ireland are } \\
\text { connected to the continent. } \\
\text { No breton tip. }\end{array}$ \\
\hline HadGEM2-ES & $\begin{array}{l}\text { Met Office } \\
\text { Hadley center, } \\
\text { England }\end{array}$ & HadGOM2 & $0.3^{\circ}-1^{\circ} \times 1^{\circ}$ & HadGAM2 & $1.25^{\circ} \times 1.875^{\circ}$ & $\begin{array}{l}\text { No English Channel, } \\
\text { England and Ireland are } \\
\text { connected to the continent. } \\
\text { No breton tip. }\end{array}$ \\
\hline MPI-LR & MPI, Germany & MPI-OM & $1^{\circ} \times 1.4^{\circ}$ & ECHAM6 & $1.875^{\circ} \times 1.875^{\circ}$ & realistic \\
\hline MPI-P & MPI, Germany & MPI-OM & $1^{\circ} \times 1.4^{\circ}$ & ECHAM6 & $1.875^{\circ} \times 1.875^{\circ}$ & realistic \\
\hline MPI-MR & MPI, Germany & MPI-OM & $0.5^{\circ} \times 0.5^{\circ}$ & ECHAM6 & $1.875^{\circ} \times 1.875^{\circ}$ & realistic \\
\hline GFDL-CM3 & NOAA, US & MOM4-Tripolar & $1^{\circ} \times 1^{\circ}$ & AM2 & $2^{\circ} \times 2.5^{\circ}$ & $\begin{array}{l}\text { No English Channel. } \\
\text { England connected to the } \\
\text { continent. }\end{array}$ \\
\hline GFDL-ESM2G & NOAA, US & TOPAZ-Tripolar & $1^{\circ} \mathrm{x} 1^{\circ}$ & AM2 & $2^{\circ} \times 2.5^{\circ}$ & realistic \\
\hline GFDL-ESM2M & NOAA, US & MOM4-Tripolar & $1^{\circ} \times 1^{\circ}$ & AM2 & $2^{\circ} \times 2.5^{\circ}$ & $\begin{array}{l}\text { No English Channel. } \\
\text { England connected to the } \\
\text { continent. }\end{array}$ \\
\hline
\end{tabular}

Tab1 : CMIP5 climate models used in the study. Name of the global model, names and resolutions of the ocean and atmosphere models, characteristics of the ocean model horizontal grid around Brittany. 


\begin{tabular}{|c|c|c|c|}
\hline Characteristic & Indice & Definition & Computing methodology \\
\hline \multirow{5}{*}{$\begin{array}{l}\text { Mean seasonal } \\
\text { cycle }\end{array}$} & I1 & annual mean & average of the 365-day time series \\
\hline & I10 & winter mean (DJF) & $\begin{array}{l}\text { average of the 90-day time series } \\
\text { (December-January-February) }\end{array}$ \\
\hline & I11 & spring mean (MAM) & $\begin{array}{l}\text { average of the 90-day time series } \\
\text { (March-April-May) }\end{array}$ \\
\hline & $\mathrm{I} 12$ & summer mean (JJA) & $\begin{array}{l}\text { average of the 90-day time series } \\
\text { (June-July-August) }\end{array}$ \\
\hline & I13 & autumn mean (SON) & $\begin{array}{l}\text { average of the 90-day time series } \\
\text { (September-October-November) }\end{array}$ \\
\hline \multirow[t]{3}{*}{$\begin{array}{l}\text { Seasonal } \\
\text { extremes } \\
\text { and amplitude }\end{array}$} & I2 & annual minimum & $\begin{array}{l}\text { preprocessing of the } 365 \text {-day time series (see note } \\
\text { in table caption); } \\
\text { computation of the annual minimum. }\end{array}$ \\
\hline & I3 & annual maximum & $\begin{array}{l}\text { preprocessing of the } 365 \text {-day time series (see note } \\
\text { in table caption); } \\
\text { computation of the annual maximum. }\end{array}$ \\
\hline & I4 & annual amplitude & $\begin{array}{l}\text { difference between the annual maximum and the } \\
\text { annual minimum. }\end{array}$ \\
\hline \multirow[t]{5}{*}{$\begin{array}{l}\text { Seasonal } \\
\text { time course }\end{array}$} & I5 & $\begin{array}{l}\text { date of the minimum } \\
\text { annual temperature }\end{array}$ & $\begin{array}{l}\text { preprocessing of the } 365 \text {-day time series (see note } \\
\text { in table caption); } \\
\text { day of the year for which the temperature is } \\
\text { minimum. }\end{array}$ \\
\hline & I6 & $\begin{array}{l}\text { date of the maximum } \\
\text { annual temperature }\end{array}$ & $\begin{array}{l}\text { preprocessing of the } 365 \text {-day time series (see note } \\
\text { in table caption); } \\
\text { day of the year for which the temperature is } \\
\text { maximum. }\end{array}$ \\
\hline & I7 & date of the spring onset & $\begin{array}{l}\text { preprocessing of the } 365 \text {-day time series (see note } \\
\text { in table caption); } \\
\text { day at which the current increasing temperature is } \\
\text { equal to its annual mean ( } 0 \text {-phase time) }\end{array}$ \\
\hline & I8 & date of the autumn onset & $\begin{array}{l}\text { preprocessing of the } 365 \text {-day time series (see note } \\
\text { in table caption); } \\
\text { day at which the current decreasing temperature is } \\
\text { equal to its annual mean (pi-phase time) }\end{array}$ \\
\hline & I9 & $\begin{array}{l}\text { duration of the warm } \\
\text { season }\end{array}$ & $\begin{array}{l}\text { preprocessing of the } 365 \text {-day time series (see note } \\
\text { in table caption); } \\
\text { length of the within-year period when the } \\
\text { temperature is higher than its annual mean. }\end{array}$ \\
\hline
\end{tabular}

Tab. 2 Presentation of indices. Characteristics, number, definition, computing methodology applied for each year. A preprocessing1 has to be applied for each year to the 365-day times series before the calculation of indices I2 to I9, following Wyrtki (1965) and Saulquin and Gohin (2010).

1For each year, the 365-day time series is fitted with a least-square algorithm to a biharmonic signal of the form

$$
T=T_{0}+T_{1} \cos \left(\omega t-\phi_{1}\right)+T_{2} \cos \left(2 \times \omega t-\phi_{2}\right)
$$

where $\mathrm{T}$ is the temperature, $\omega=\frac{2 \pi}{\tau}$ the omega-frequency with $\tau=365$ days, and $\mathrm{t}$ the time (in days) starting from the beginning of January. $T_{0}$ is the average annual temperature, $T_{1}$ and $T_{2}$ are the amplitudes and $\varphi 1$ and $\varphi 2$ the phases of the annual and semi-annual harmonics, respectively. For each year, the coefficients $T_{0}, T_{1}, T_{2}, \varphi 1$ and $\varphi 2$ that best fit the 365-day time series are estimated and a biharmonic SST signal reconstructed, with a daily time resolution. The biharmonic SST signal is used to compute the yearly value of the indices I2 to I9. The indices I7 to I9 are estimated using the 0-phase and pi-phase time variables defined in Eliseev and Mokhov (2003), derived from the annual cycle amplitude-phase characteristic method. 


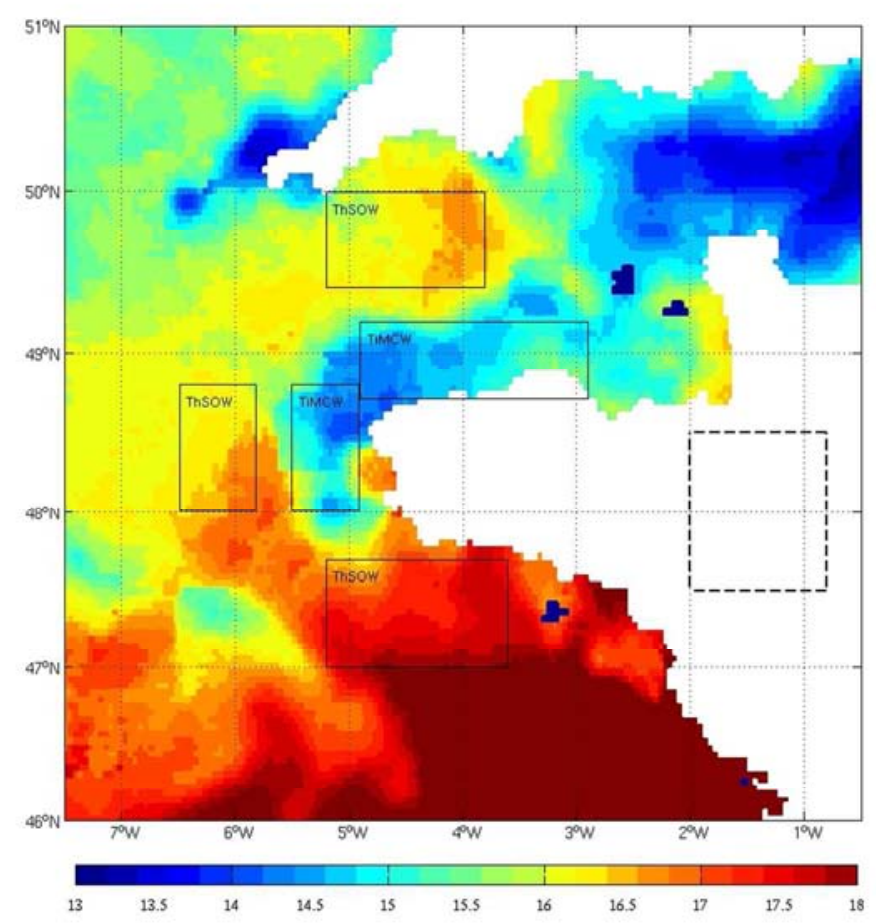

Figure 1: Snapshot of the SST on 18th June 2003 from Ifremer satellite-derived data. Selected ThSOW and TiMCW areas in the Iroise Sea, the English Channel and the Bay of Biscay (solid line). A typical grid cell size for CMIP5 models (dashed line), representative of the grid cell size of 10 models over the 13 models of the study.

$423 \times 317 \mathrm{~mm}(72 \times 72 \mathrm{DPI})$ 

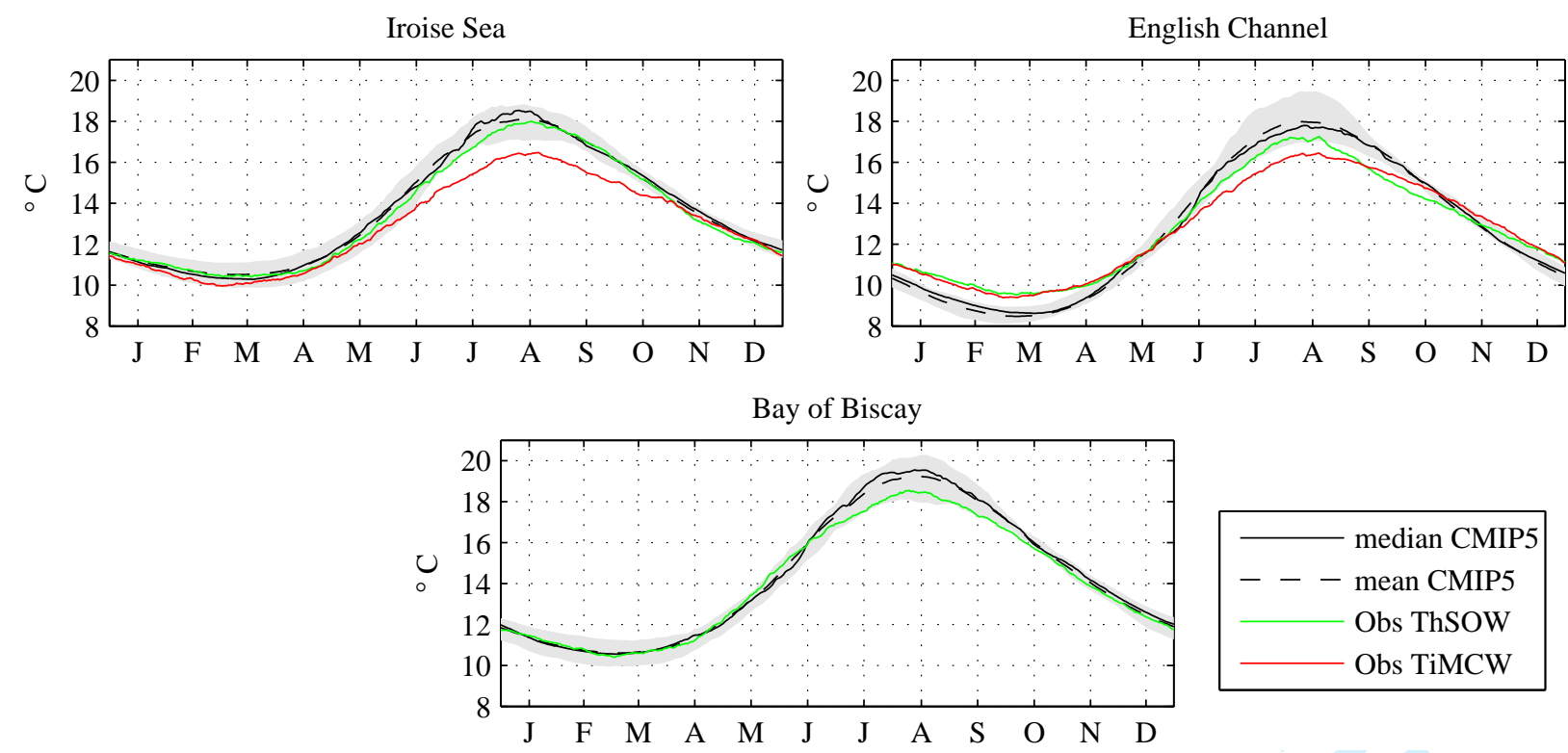
(a) CMIP5 vs TiMCW

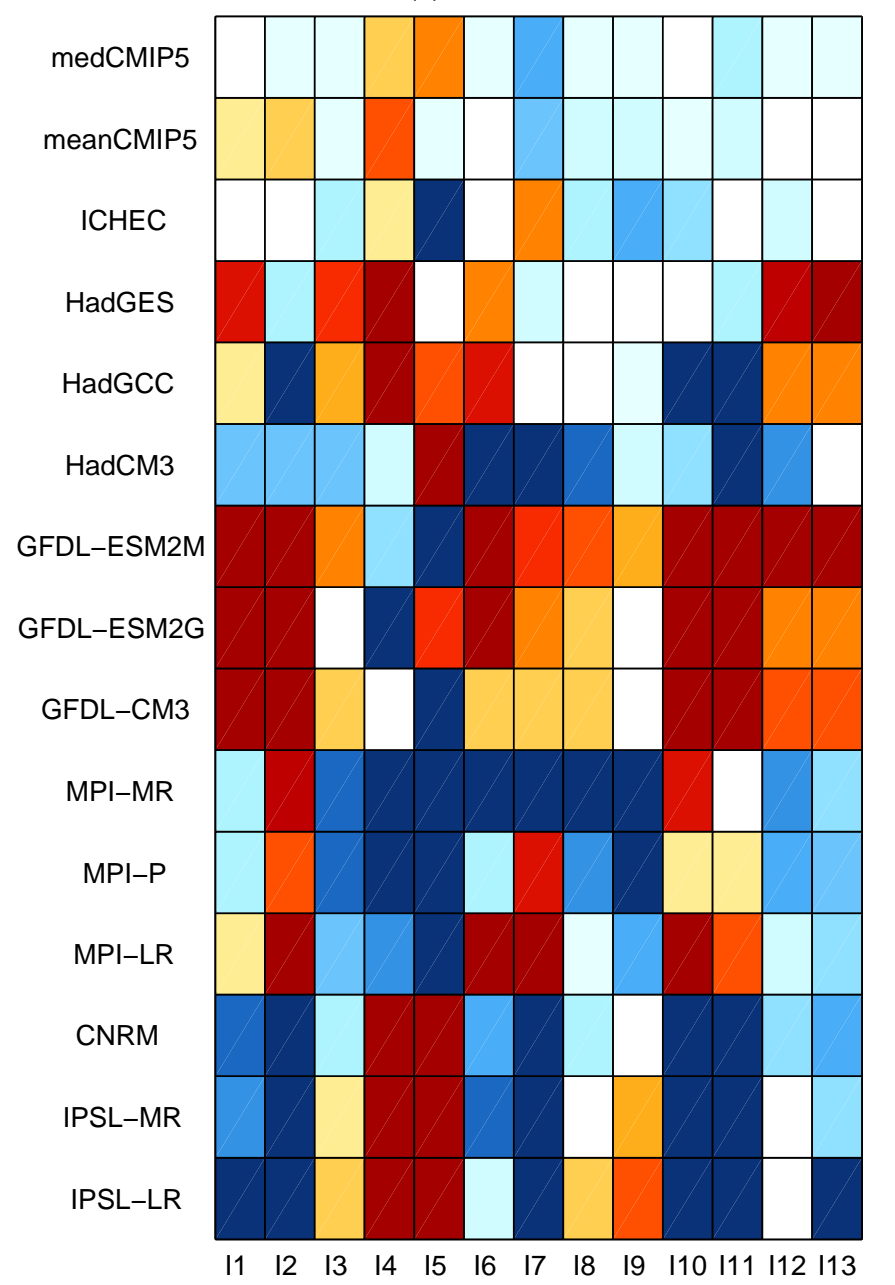

(b) CMIP5 vs ThSOW

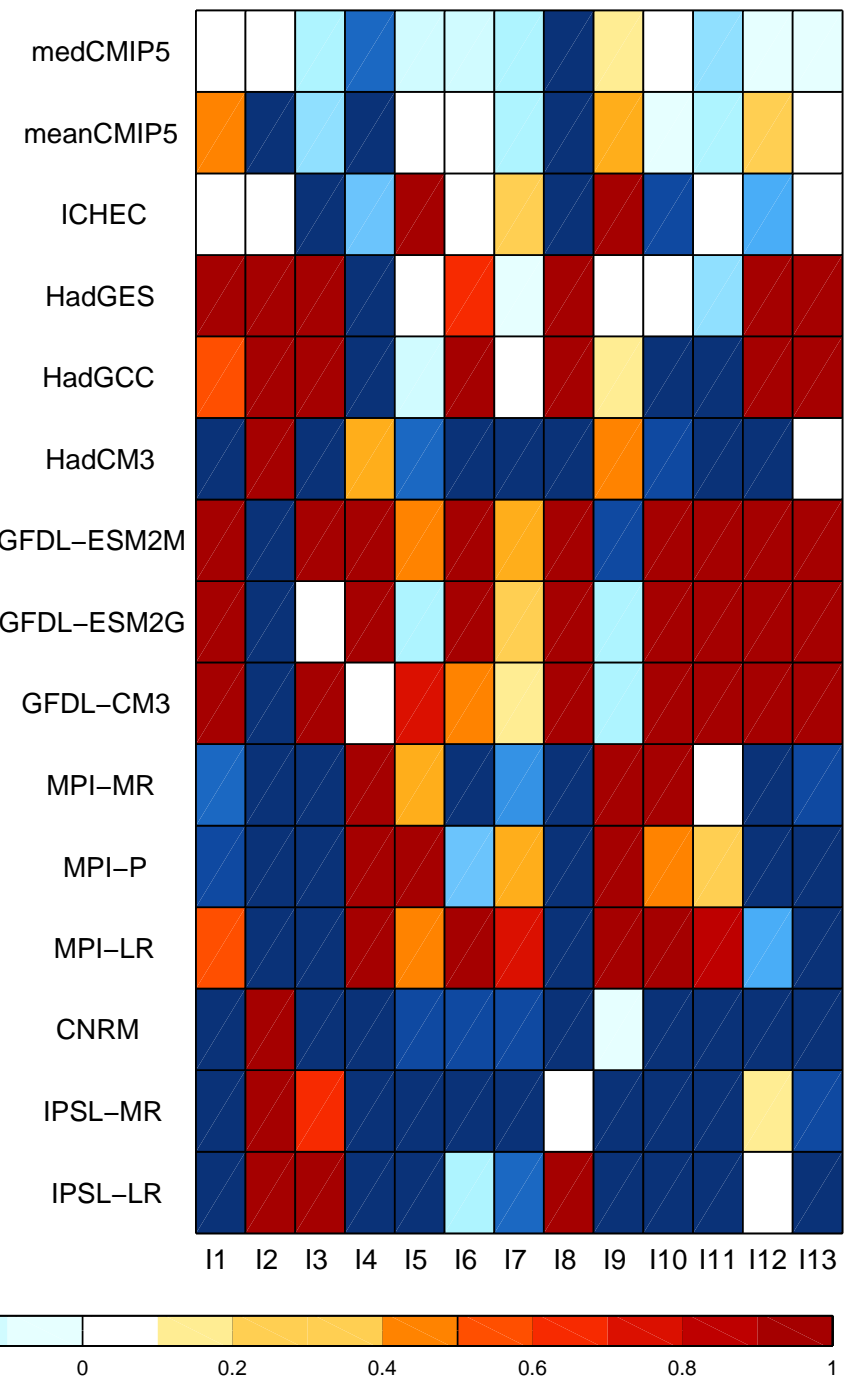



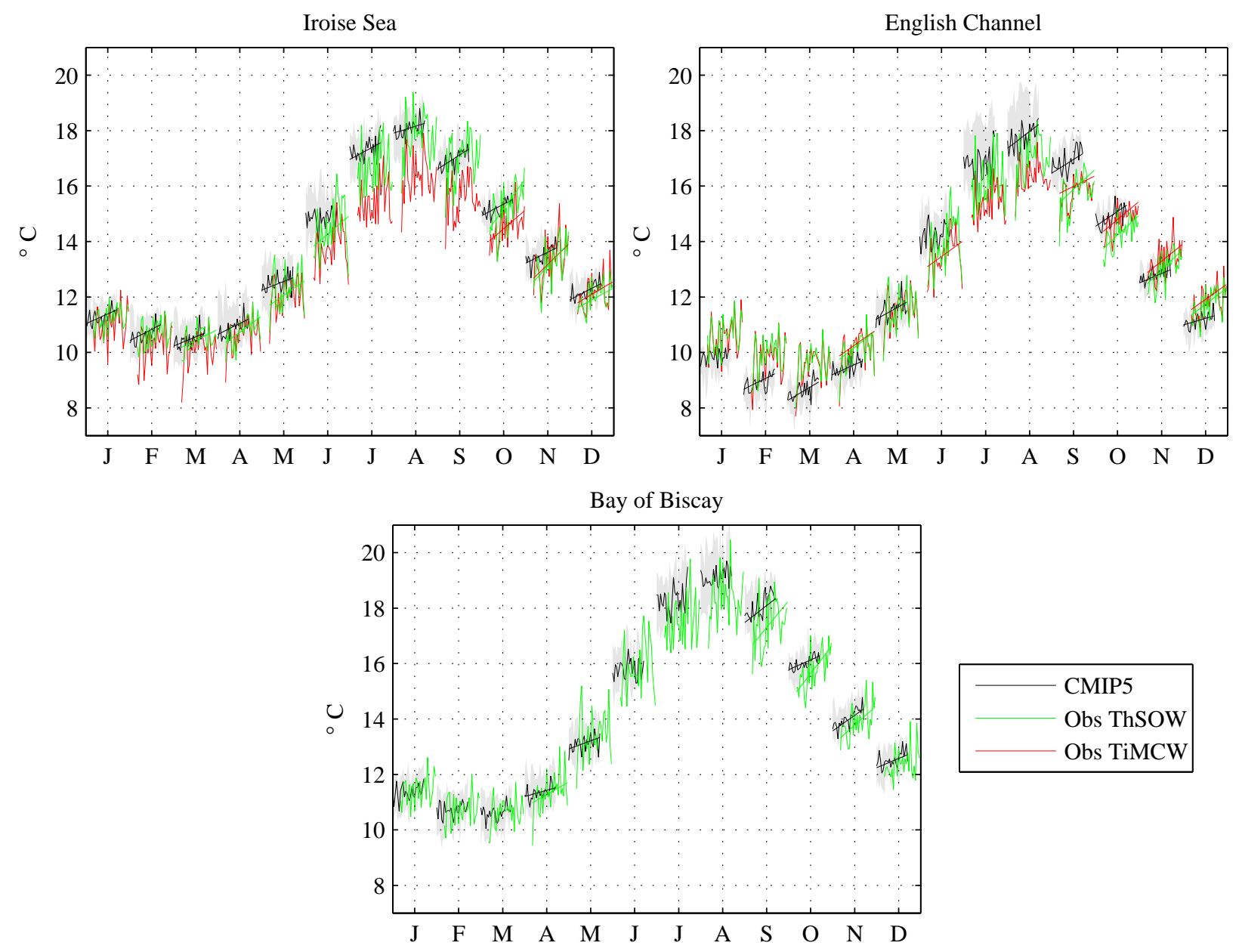

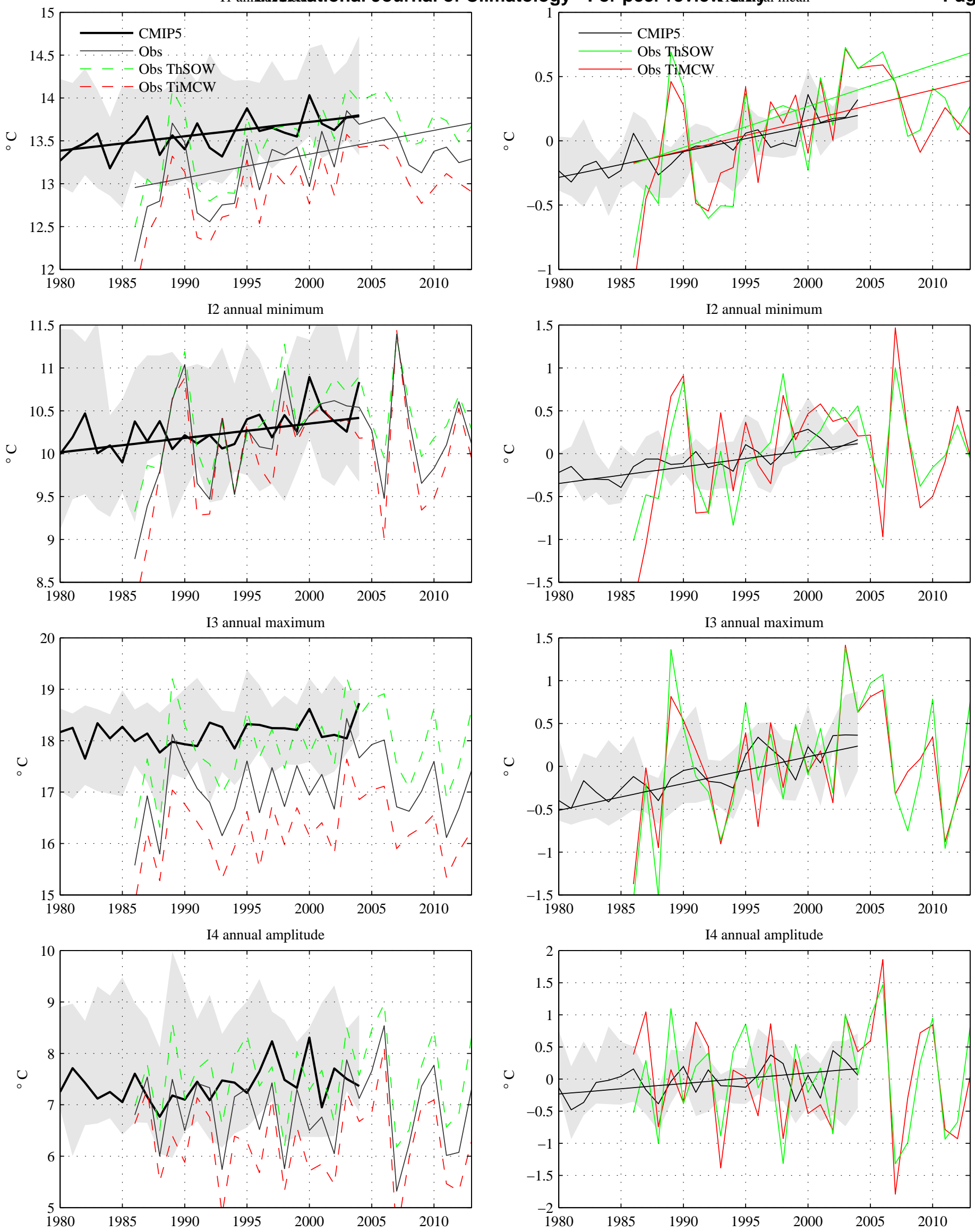

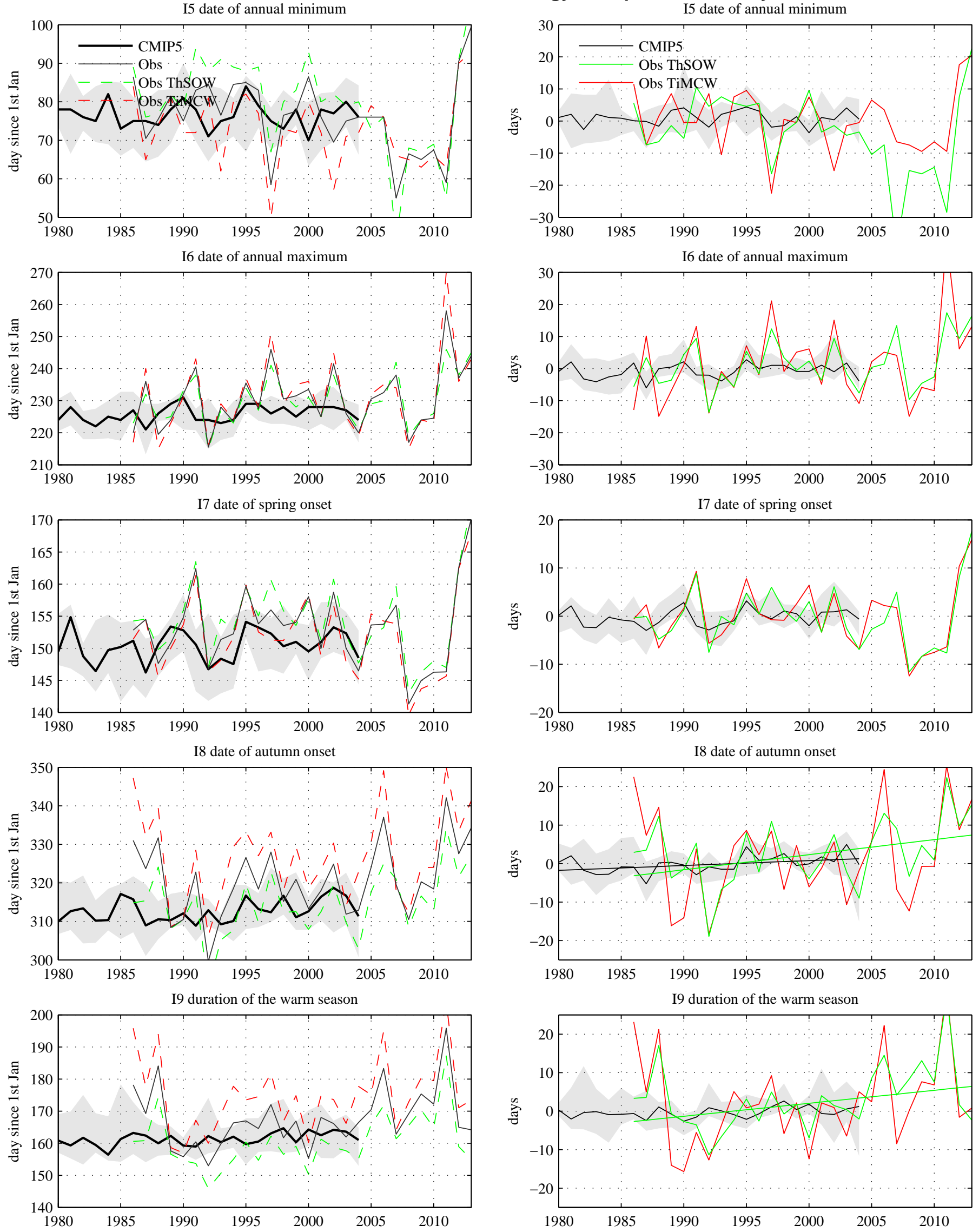

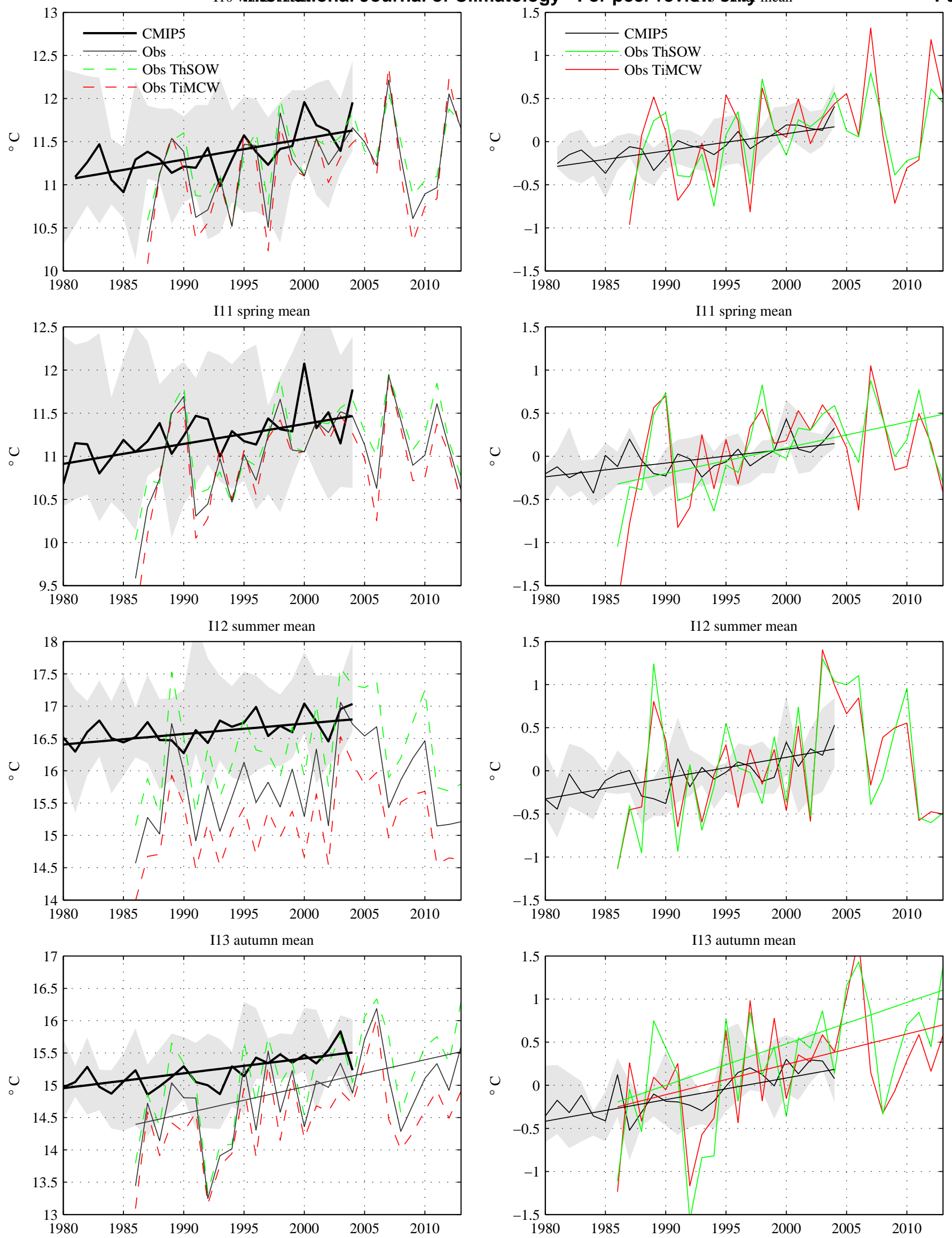

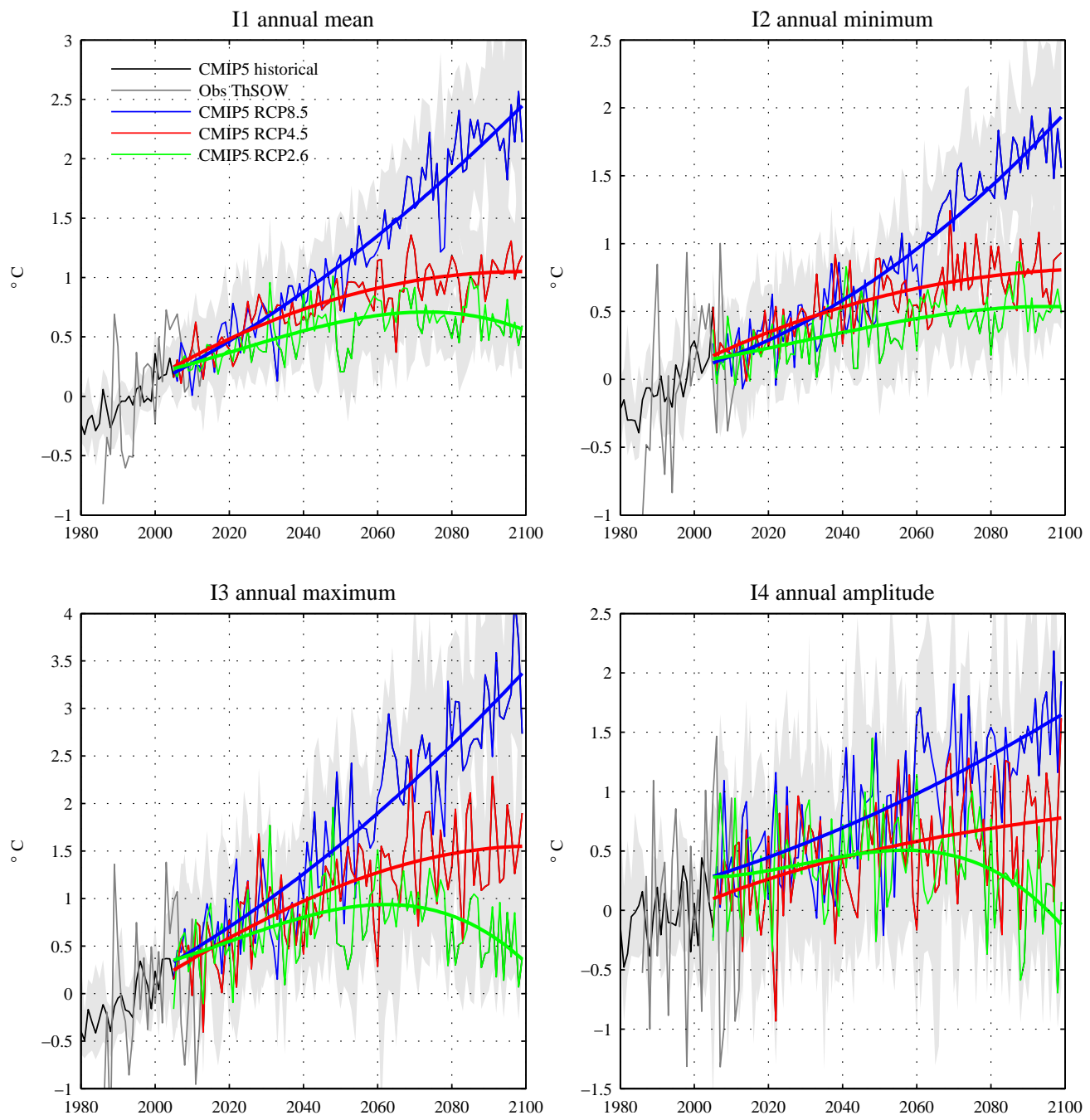

http://mc.manuscriptcentral.com/joc 

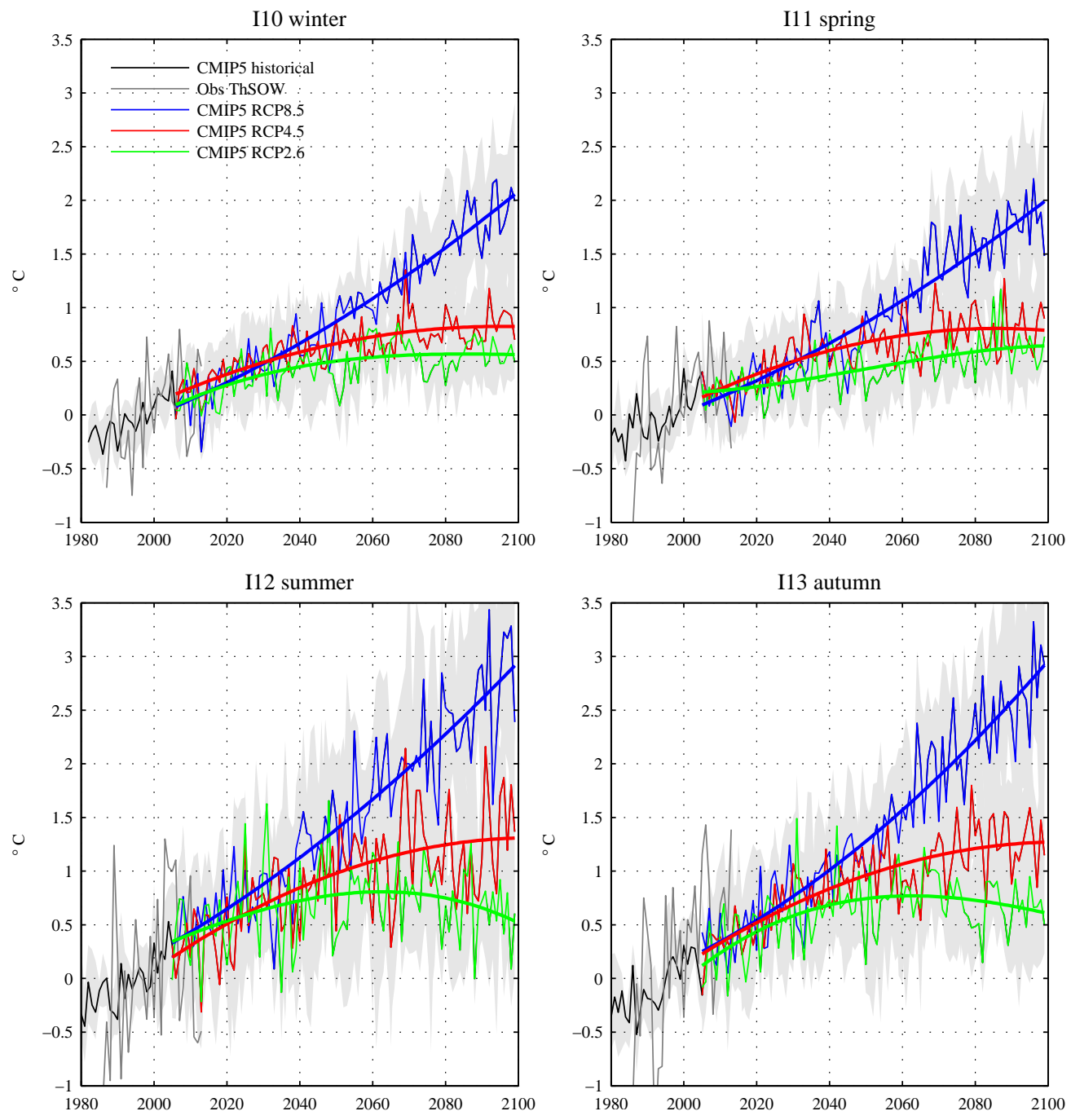

http://mc.manuscriptcentral.com/joc 
(a) PDF Winter mean (present \& near future)

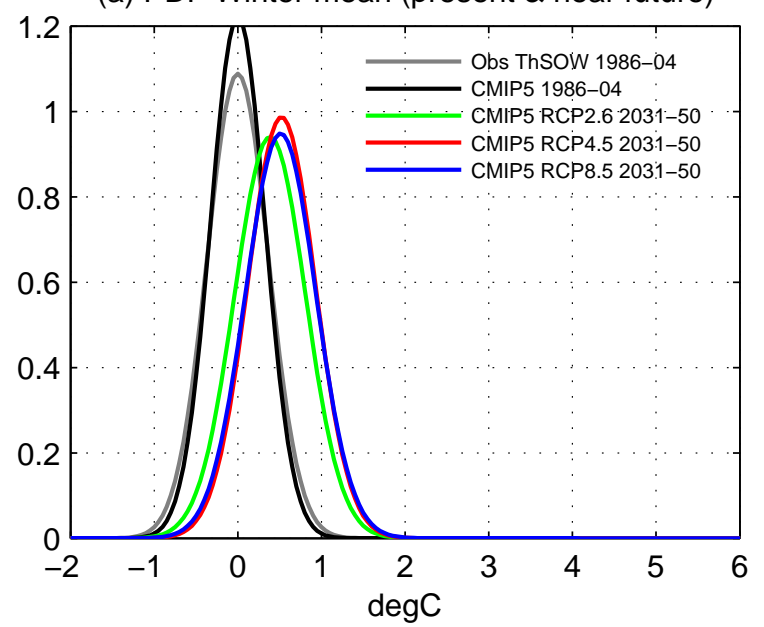

(c) PDF Summer mean (present \& near future)

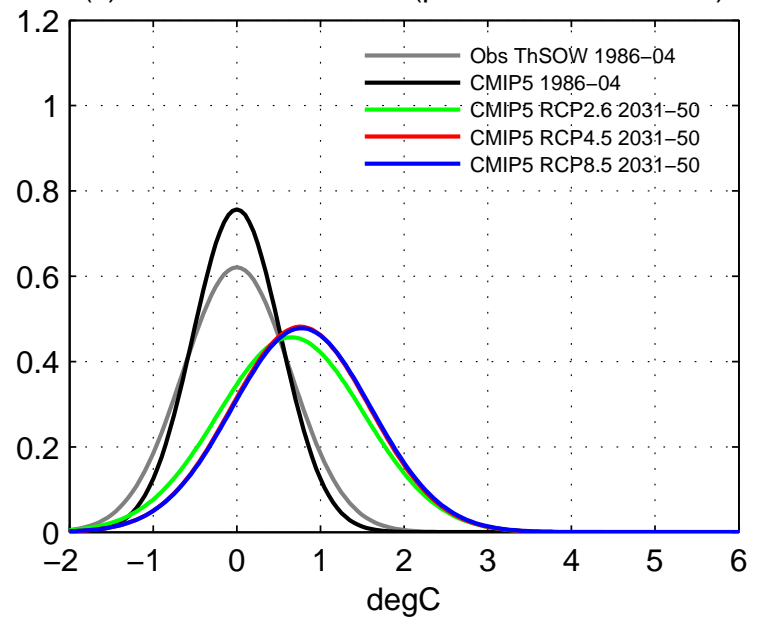

(b) PDF Winter mean (present \& far future)

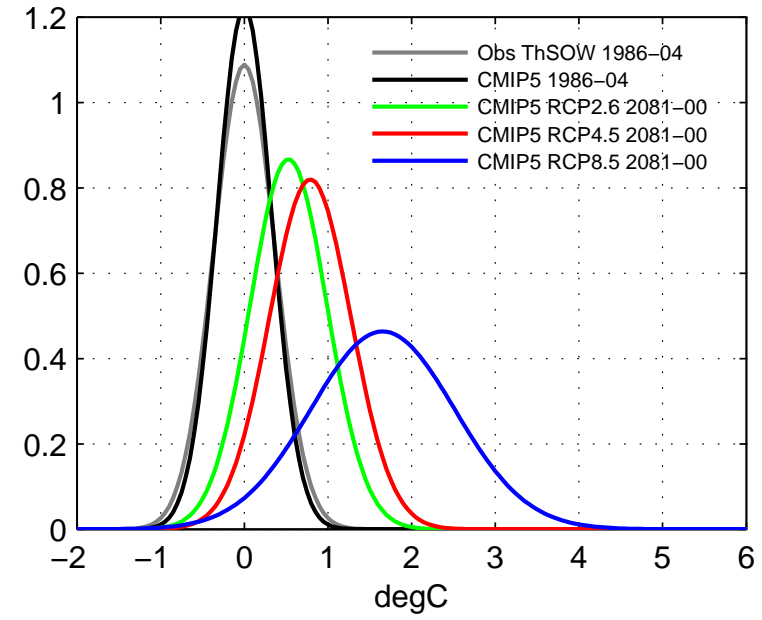

(d) PDF Summer mean (present \& far future)

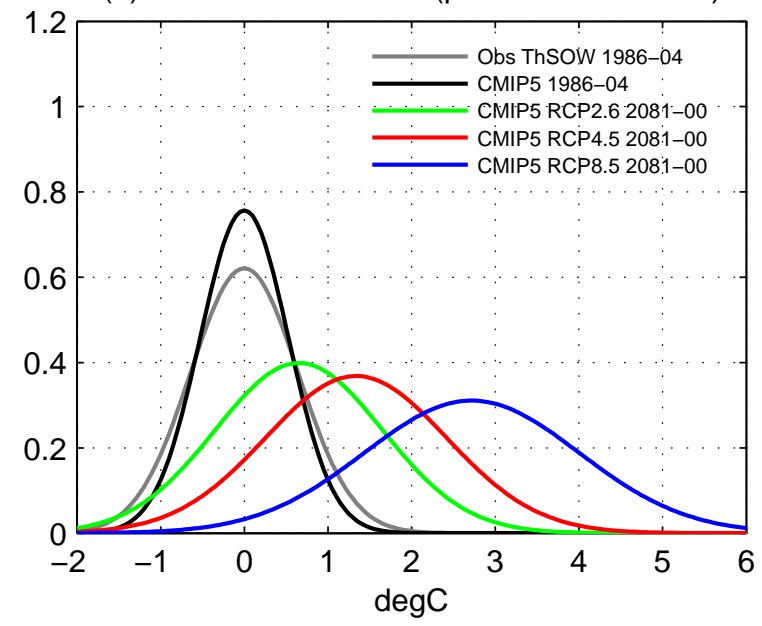

